\title{
Agricultural Water Pricing: EU and Mexico
}
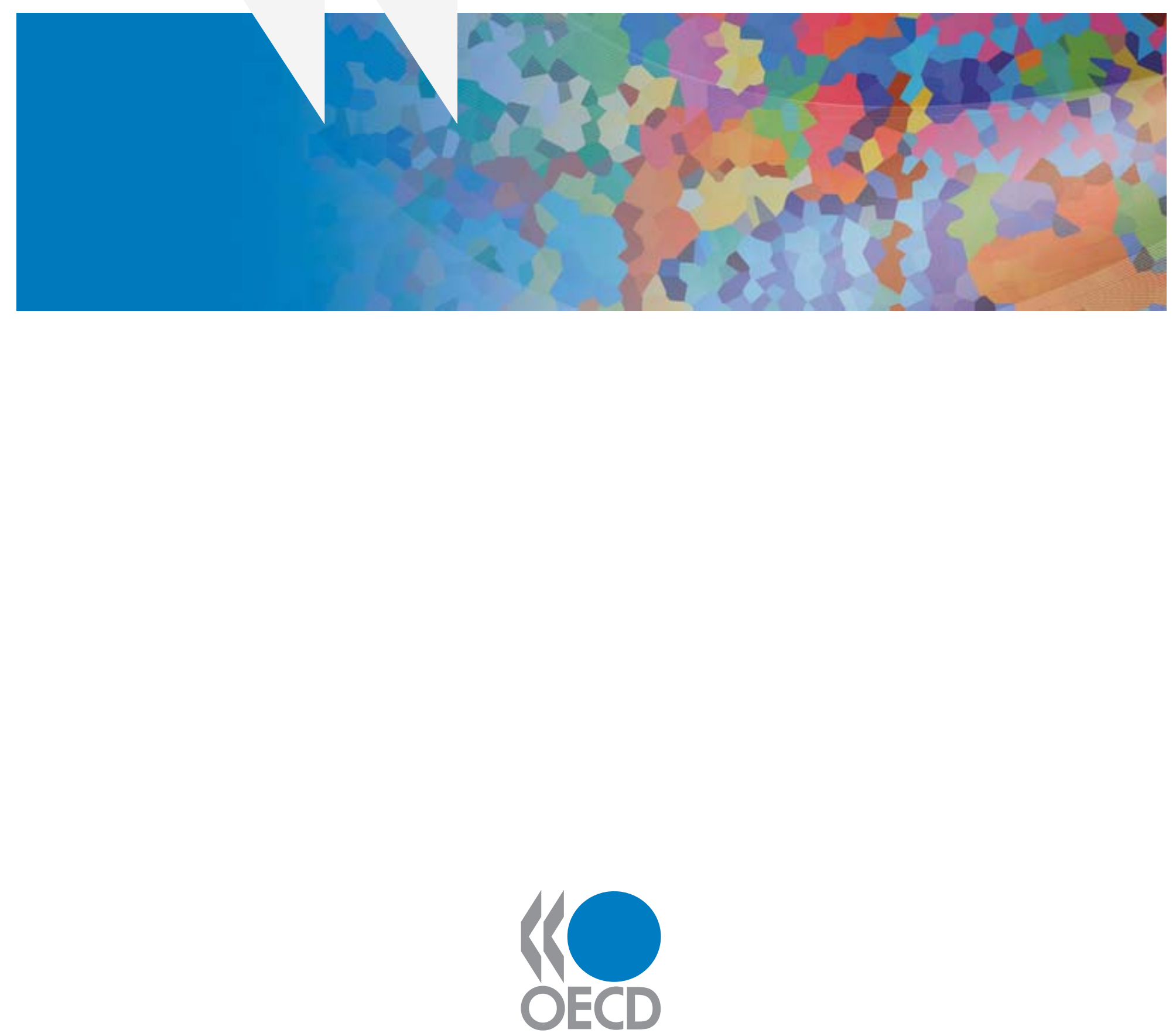


\section{ORGANISATION FOR ECONOMIC CO-OPERATION AND DEVELOPMENT}

The OECD is a unique forum where the governments of 30 democracies work together to address the economic, social and environmental challenges of globalisation. The OECD is also at the forefront of efforts to understand and to help governments respond to new developments and concerns, such as corporate governance, the information economy and the challenges of an ageing population. The Organisation provides a setting where governments can compare policy experiences, seek answers to common problems, identify good practice and work to co-ordinate domestic and international policies.

The OECD member countries are: Australia, Austria, Belgium, Canada, the Czech Republic, Denmark, Finland, France, Germany, Greece, Hungary, Iceland, Ireland, Italy, Japan, Korea, Luxembourg, Mexico, the Netherlands, New Zealand, Norway, Poland, Portugal, the Slovak Republic, Spain, Sweden, Switzerland, Turkey, the United Kingdom and the United States. The Commission of the European Communities takes part in the work of the OECD.

(c) OECD 2010 


\title{
Agricultural Water Pricing: EU and Mexico
}

\author{
ALBERTO GARRIDO \\ UNIVERSIDAD POLITÉCNICA DE MADRID, SPAIN
}

AND

JAVIER CALATRAVA

UNIVERSIDAD POLITÉCNICA DE CARTAGENA, SPAIN 



\begin{abstract}
Note
This document, Agricultural Water Pricing: EU and Mexico, by Alberto Garrido of the Universidad Politécnica de Madrid, and Javier Calatrava, of the Universidad Politécnica de Cartagena, Spain, is one of the background reports supporting the OECD study (2010) Sustainable Management of Water Resources in Agriculture, which is available at www.oecd.org/water.

The report was carried out under the auspices of the OECD Joint Working Party on Agriculture and the Environment of the Committee for Agriculture and the Environment Policy Committee. The report is published under the responsibility of the author and does not necessarily reflect the views of the OECD or its member countries.
\end{abstract}

The other background reports (also available at www.oecd.org/water) are:

An Economic Analysis of the Virtual Water Concept in Relation to the Agri-food Sector Dennis Wichelns, Hanover College, United States http://dx.doi.org/10.1787/786736626756

Agriculture's Role in Flood Adaptation and Mitigation - Policy Issues and Approaches Joe Morris, Tim Hess and Helena Posthumus, Cranfield University, United Kingdom http://dx.doi.org/10.1787/786804541573

Environmental Effectiveness and Economic Efficiency of Water Use in Agriculture: The Experience of and Lessons from the Australian Water Reform Programme Michael D. Young, University of Adelaide, Australia http://dx.doi.org/10.1787/786732081512

Financing Water Management and Infrastructure Related to Agriculture across OECD Countries Frank A. Ward, New Mexico State University, United States http://dx.doi.org/10.1787/786788524232

Agricultural Water Pricing in Japan and Korea James E. Nickum and Chisa Ogura, Asian Water and Resources Institute, Japan http://dx.doi.org/10.1787/787011574235

Agricultural Water Pricing in Turkey

Erol H. Cakmak, Middle East Technical University, Turkey

http://dx.doi.org/10.1787/787034266022

Agricultural Water Pricing: Australia

Seamus Parker, Council of Mayors (South-East Queensland); and

Robert Speed, Freelance Consultant, Australia

http://dx.doi.org/10.1787/787105123122

Agricultural Water Pricing: United States

Dennis Wichelns, Hanover College, United States

http://dx.doi.org/10.1787/787165082115 


\section{Table of Contents}

Executive Summary ....................................................................................................

Introduction: Background, scope objectives ..........................................................

Review of recent literature on agricultural water pricing ..........................................

The definition and components of the costs of supplying water for irrigation .............17

Country case studies: France, Greece, Italy, Portugal, Spain and Mexico.....................19

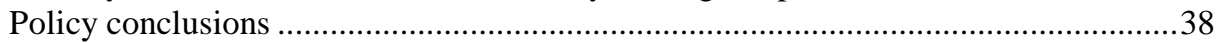

Bibliography .............................................................................................42 


\section{Executive Summary}

The key objective of the study is to provide an empirical study of agricultural water pricing (for irrigation) across five European Union countries where irrigation is important and Mexico, examining agricultural water price ranges and characteristics, and the extent to which the price paid by irrigators for water recovers operation and maintenance costs, and capital costs (i.e. renewal investment and new investment) for water delivery to the farm (i.e. full supply costs). Water pricing can go beyond full supply recovery rates and charge physical consumption of water resources, as a means to ensure more efficient use (i.e. full cost recovery).

Under the EU Water Framework Directive (2000, hereafter referred by WFD) many EU countries are reforming their water pricing and financing policies towards full cost recovery, including the pricing of water for agriculture. Clear definitions of irrigation water costs and methodologies to estimate irrigation water costs and cost recovery rates, however, have been detailed by the European Commission Wateco Guidelines. In practice, there are still significant difficulties in (a) collecting the adequate data at the lowest possible scale; (b) applying proper capital cost evaluation techniques; (c) evaluating the resource and environmental costs, in a way that can be officially integrated in the water tariffs; and (d) performing comparative analyses across countries' tariffs and cost-recovery rates.

Based on Article 27 of the Mexican Constitution and the National Water Law of 1992, Mexico embarked on an ambitious program of transferring the management of many irrigation systems to local user groups, primarily farmers. By 1996, 372 water user associations had been formed to control water deliveries to 2.92 million hectares. Along with this came also the turning over to their corresponding WUAs of the entire management of the districts' finance and economic administration, including charging irrigation fees and cost recovery schemes. The so-called Irrigation Management Transfer would span a 15-year period providing important lessons for countries embarking on devolution schemes of grand scale.

Comparable cross country information on the institutional arrangements for agricultural water pricing are now available and well documented. Most OECD countries, especially the six reviewed in this report, follow similar approaches towards water rights definition and the pricing of irrigation water. But there are differences in the way government agencies implement national/regional water policies and manage the resources. The institutional set-up and actual competences of the basin agencies differ in some sense among of the EU member states reviewed in the document. However, new data sources and documentation are now available that permit a better diagnosis about the use of pricing instruments, and the use of cost-recovery charges, adding to previous OECD studies (OECD, 2001). A robust finding from this study is that water subsidies in the form of low to very low capital costs' recovery are common in the EU and Mexico. The extent to which capital costs are subsidised is extremely difficult to ascertain because each country follows specific criterions to evaluate capital costs, and most available data is reported at aggregate level (basin or even national), except for a few detailed studies. 


\section{Introduction: Background, scope objectives}

The irrigation sector is the largest user of global water resources. Commonly, capital investments are needed to move water from the natural water bodies to the irrigation fields. The long-term development and building of irrigation projects may require that governments plan, finance and implement them. In many cases, government agencies also get involved in running and managing the irrigation schemes. Tariffs are charged only when the scheme becomes operative, although provisions are made to recoup part of the financial and amortisation costs and cover the entire O\&M costs.

When water is taken from aquifers, most or all capital is privately provided by the farmers themselves or by small-scale collective organisations. In this situation, there are often no water prices or tariffs. In the EU, some countries have imposed water tariffs for groundwater, including France, The Netherlands, Denmark, and England and Wales. When groundwater has been used unsustainably by farmers, very few agencies have resorted to use tariffs as use deterrents and most have established quotas, caps or zonification.

This means that irrigation water pricing, as a contentious policy issue, is primarily focused on surface water and where infrastructures have been built to convey water from the source to the fields. These infrastructures are privately, publicly or jointly public-private financed. An overwhelming majority of the water pricing experiences focus on the latter two cases.

Against this general setting, the key objective of the study is to provide an empirical study of agricultural water pricing (for irrigation) across EU countries and Mexico where irrigation is important. It examines agricultural water price ranges and modalities, and the extent to which the price paid by irrigators for water recovers operation and maintenance costs and capital costs (i.e. renewal investment and new investment) for water delivery to the farm (i.e. full supply costs).

Under the EU Water Framework Directive (EC, 2000) many EU countries are reforming their water pricing and financing policies towards full cost recovery, including the pricing of water for agriculture. Implementation of cost recovery prices should be done by 2010. Clear definitions of irrigation water costs and methodologies to estimate irrigation water costs and cost recovery rates, however, are weak, and the study should seek to address this issue. However, specific methodologies used to establish the tariffs are not available from the countries' official sources. It seems also that numerous exceptional rules, specificities and contexts prevent drawing common conclusions even for a single country. The WFD is mainly an environmentally oriented legislation, so its economic instruments are oriented towards environmental objectives, namely the water quantity and quality.

Comparable cross country information on the institutional arrangements for agricultural water pricing is incomplete and the study would seek to address this information gap by providing data on the: types of water property rights; pricing agencies; use of economic instruments in water pricing; and the extent of intersectoral water competition. 


\section{Review of recent literature on agricultural water pricing}

Since the publication of OECD (1999) there have been a number of new studies focusing in irrigation water pricing. Molle and Berkoff (2007) compiled a thorough analysis of pricing policies around the world, touching on multiple aspects related to water policy reform primarily in developing countries. A similar encompassing source is Tsur et al. (2004), though this one does not cover EU countries.

Up to know, very few works have analysed the impacts of water pricing, either establishing, reforming or increasing water tariffs. Most conclusions are based on simulation or math programming models (Berbel et al. 2007; Mejías et al. 2004; Bartolini et al. 2007; Semaan et al. 2007; Riesgo and Gómez-Limón 2006; Bazzani et al. 2005; Scheierling et al. 2004). In general, demand models tend to overestimate the income impact of pricing policies and to underestimate the water demand elasticity resulting from the analysis. The reason for this bias may be that most modelling efforts look at short or, at most, medium term responses. However, Molle and Berkoff (2007) provide an extensive and detailed argument for reducing the expectations politicians and analysts should have with respect to irrigation water pricing. In our view, positive models that rely on optimisation models may not incorporate many uncertainties involved in farming decisions to the extent that they operate in the real world. It would be interesting to contrast analyses based on cross-sections of farmers' water usages and prices with those mentioned above. The literature so far is skewed towards the use of positive models.

In the following sections ${ }^{1}$ we summarise the major findings about connections of irrigation pricing policies with cost recovery rates, environmental effects, water demand, farm income and productivity. Most studies applied in the EU look also at the combined effects of agricultural and water policies.

\section{Cost recovery}

WFD supports the achievement of economic objectives, specifically full cost recovery for water services, including environmental and resource cost within each of the three sectors: agriculture, industry and domestic. WFD bases the concept of cost recovery on the concept of 'water services,' and the complete meaning of this sentence has been defined in detail in the WATECO guide (EC, 2003) that develops the concept of cost recovery by stating two levels of recovery: 'financial' (i.e. full supply costs) and 'environmental and resource' costs (i.e. full cost recovery).

In a perfect competitive market, the prices fall out of the market through the interaction of the buyers and sellers, and the optimum allocation of water is automatically achieved. But with water, and specifically in relation to environmental uses, the prices have to be 'invented.' The problem is to establish a set of prices that results in achieving the optimum allocation of water. In many cases, the charges for irrigation in the EU countries and Mexico, as in most other countries, have been inadequate to fully recover capital and operating costs. Other levels of recovery have been introduced largely in regard to the issue of allocating the water between competing uses, in particular, between human and environmental uses.

The concept of 'water services' is defined in monetary terms as the economic cost of building and maintaining infrastructures and supplying water. This analysis should be done for the agriculture, industry and domestic urban water sectors. Additionally, on top of these monetary costs, WFD requires the estimation of both environmental and resource costs, and the definition of a programme to recover them. Differences between 'environmental cost' and 'resource cost' are difficult to implement in the real world. It would have probably been more useful to separate 'monetary' (O\&M, depreciation, financial) and 'non-monetary' (environmental and resource) costs.

1. These sections borrow from Berbel, Garrido and Calatrava (2007), but have been summarised and updated with more recent literature and findings. 
Resource costs are the most difficult to quantify. Usual notions of resource costs associate them with opportunity costs that are equivalent to the economic value of the opportunities forgone when allocating the resource to a given user. When water markets exist, resource costs can be assimilated to the market price of water netted of the costs incurred abstracting or moving the water to its final destiny.

The difficulties of separating cost items are related to the different definitions of 'full-cost recovery' prices that each country appears to follow. Appropriate policy action should also recognize that an irrigator's water use may entail additional social costs. These social costs may or may not be included in the definition of 'full-cost recovery' rates, but it would certainly be in the interests of society to identify them and attempt to reduce them. The following sections clarify these notions and provide cost evaluations found in the literature and recent reports. We will use the following typology for monetary costs: a) Private Farmer Costs, b) Irrigation Scheme Costs and c) Public Water Authority Costs.

\section{Private (on-farm) costs}

Private irrigation costs include those items for which the irrigator is entirely responsible, and that farmers generally pay as any other farm and cultivation costs, such as maintenance, energy and labour. There are two main drivers for the increased area under precision irrigation (drip irrigation): the scarcity of water and the scarcity of labour, which make automatic irrigation systems very attractive for farmers who face the rising cost of both inputs. In the EU, as one gets to Northern latitudes, waterways are commonly accessible to farmers who can easily pump water out for supplemental irrigation. In these cases, as well as in groundwater irrigation, all costs are private and borne by the farmers themselves.

\section{Irrigation district or scheme costs}

Irrigation districts distribute both surface water and, less frequently, groundwater to individual farmers, and the costs of running and maintaining infrastructure and associated facilities serving a clearly identified set of irrigators are in principle paid by farmers irrespective of the kind of ownership of the district's infrastructure. In practice, there is abundant evidence of better district cost recovery in private associations than in state-run or publicly owned water infrastructure (OECD, 1999a). Most schemes are managed by irrigation districts, which usually are non-profit associations with legal status.

In countries such as Italy, Spain, Portugal, Turkey or Mexico irrigation districts are assigned an instrumental role in water policy implementation and water management. According to the Spanish Water Law, irrigation districts (more than 6,500 Comunidades de Regantes are registered, covering 2 Mha) must have their statutes and bylaws approved by the Basin Agencies and perform a number of key tasks in water management. For instance, they collect farmers' charges and levies charged by the Basin Agency and transfer the revenue to the latter. They have also approved procedures to solve conflicts among irrigators, organize irrigation turns and develop and co-finance rehabilitation projects.

User associations in Spain are mostly collective organizations, irrespective of whether they are served with public concessions (either surface water or groundwater) or from private groundwater rights. The French Associations Syndicales Autorisées (ASAs) have similar characteristics although their size is usually very small, while the Sociétés d'Aménagement Rural (SAR) are purely private organizations. In Italy, water user associations are association of landowners with public status (meaning that they are regulated by law and subject to government supervision). In Greece, the cooperative irrigation projects result from the joining of the Local Land Improvement Boards (TOEV) and the National Land Improvement General Boards (GOEV), being the former the responsible of running the collective irrigation schemes.

Water distribution systems in Italy mainly rely on "Reclamation and Irrigation Boards" (RIBs) (Consorzi di Bonifica e Irrigazione), that are managed by associations of landowners, entities 
regulated by public law that control land reclamation and water distribution in a certain area. RIBs distribute about $90 \%$ of the water used for irrigation (ANBI 1992 and 1998). Consortia have selffinancing capacity to foster rural development, as well as to build irrigation projects. The government provides funds to cover all project capital costs, while the Consortia is responsible for managing and maintaining these systems, and collecting charges from farmers.

In Portugal, agricultural water tariffs are levied by users' associations in accordance with very complex mechanisms and formulae. The complexity arises because WUAs sometimes supply municipal water as well, property size affects the water charges, and charges are combined with drainage fees in projects that require drainage (Castro 1997). However, the recently irrigated land serviced from the Alqueva Dam in the Guadiana Basin (more than 100,000 ha) is managed following standard irrigation schemes.

Running costs of irrigation districts are borne solely by the irrigators. However, in most countries, investment costs, either in new schemes or in modernization or rehabilitation projects, receive significant subsidies. Most large irrigation infrastructures across OEDC countries, irrespective of when they became operative, have been built with public capital grants. New irrigation districts are projected to be developed in the next decade in Spain or Portugal, although in the case of Spain, new irrigation projects are now very limited and targeted to areas undergoing depopulation (the so-called 'social irrigation' projects).

\section{Water authority costs}

A critical methodological issue regarding cost-recovery analysis is the definition of the financial costs of the services provided by the water government agencies. The situation with regard to cost recovery status may vary for each river basin. We illustrate difficulties with this definition with an example from the Guadalquivir basin in Spain, regulated with large dams and infrastructures. The use of historical values in cost recovery is generally accepted in most of the great public infrastructure projects. Specifically for water infrastructure, many dams are older than 50 years and have been theoretically fully paid for by users (farmers and urban users) even when there is a real positive salvage value and they are still in use. Furthermore, capital replacement costs are hardly considered, so by the time infrastructure elements become obsolete or fully depreciated the flow of paid charges during the life-time would never be enough to build new ones.

We should remark that the use of 'marginal' or 'replacement cost' is not assumed in the WFD, and we may recall the water privatization in UK in the 1990s, when the final value of assets was computed neither at 'historical value' (deemed too low a price) nor at 'replacement value' (deemed an excessive price) but estimated based on the 'present value of profit' or, in other words, the ability of buyers to pay. Economic theory defines the capital value of an asset as the present value of the future stream of profit and therefore neither historical value nor replacement value is relevant. In practice, the higher the amount for which the existing assets were sold by the government when the companies were privatized, the higher the charges for water and wastewater required to provide a commercial rate of return on those assets. In contrast, in the case of irrigation, Spain has been given permission by the EU Commission to use historical depreciation criteria for determining the extent of full cost recovery rates.

Generally, difficulties in defining financial (supply) costs also arise from how the costs of multipurpose projects are distributed. In Spain, the sharing of costs between different uses is made by a 'stakeholder's agreement' at basin level, considering the following variables:

\section{- Capital cost sharing}

- Flood control: the percentage of costs assumed to provide the public service of flood control may vary from $20 \%$ (most dams in Spain) to $70 \%$ of some special Mediterranean cases (e.g. Tous dam). 
- Urban (domestic and industry) versus irrigation: normally urban users have a different quality of service (daily, seasonal, yearly secured supply) versus irrigation that, in many cases, is residual use.

- Energy (hydroelectric, refrigeration)

- Environmental use

- Recovery of O\&M: Water agencies are multifunctional as they may not only control abstraction and pollution but, sometimes, also finance infrastructures to supply water. For example, the Guadalquivir Basin Authority recovers 75\% of its O\&M costs for public infrastructures through tariffs, but the remaining $25 \%$ is linked to the cost of environmental services (pollution and flood control, etc.).

Also the computation of financial costs should determine some technical parameters such as: a) depreciation rate, b) salvage value of investment and c) interest rate.

An example of water cost recovery estimation is described by Berbel (2005) who computes costs according to the current Spanish Water Law which states a 'cost recovery formula' defining a water tariff based upon computation of water agencies' O\&M plus depreciation of water infrastructure (the depreciation rate is based upon historical costs without interest rate). When the cost definition and criteria of the Water Law are applied, we arrive at $99 \%$ of financial cost recovery. But when stricter accountancy criteria are applied including faster depreciation and 5\% interest rate, financial cost recovery is reduced to $71 \%$. Finally, this percentage may be reduced if we compare the present average tariff in the Guadalquivir River (EUR $0.0178 / \mathrm{m}^{3}$ ) with the 'replacement cost' of EUR $0.06 / \mathrm{m}^{3}$ (full recovery rates for 'La Breña-2 dam' presently under construction).

To mention another example of cost recovery we may take the last large irrigation project associated with the 'Alqueva dam' (Portugal) with a present price of $1.8 \mathrm{cent} / \mathrm{m} 3$ (not covering energy cost) but expected to reach 8 cent $/ \mathrm{m}^{3}$ in 2007 if full 'financial cost recovery' is to be achieved. This shows the importance of subsidies as the root of future water imbalances and environmental problems.

Water Authority costs include all cost items directly related to the supply of irrigation water, which are covered by water charges to users and by general taxpayers, with different degrees of cost distribution between the two groups. A common conclusion across countries is that irrigators have been, and still are, heavily subsidized, primarily in terms of insufficient capital cost-recovery.

\section{Groundwater (on-farm) costs}

Groundwater is the source of water for $20 \%$ to $100 \%$ of European irrigated farms, depending on the region and country. Irrigators using groundwater resources apparently pay all financial costs as they pay investment, maintenance and energy costs for pumping water because they are not supplied by any public scheme. Consequently, in most of the countries, users of groundwater do not pay any tariff to water authorities although some countries (France, Netherlands, Denmark and England \& Wales) charge a water abstraction fee.

\section{Social and environmental costs}

Very few studies have evaluated the environmental, job-market and GNP impacts of establishing tariffs for the use of irrigation water. A very recent exception is the study by Castellano et al. (2008). In an application of Social Accounting Matrices and GIS to the region of Navarra, they find that the environmental value, which results from the average environmental cost that internalizes the value of all the externalities generated by irrigation water consumption, is $0.0601 \mathrm{EUR} / \mathrm{m}^{3}$. The economy of Navarra has a capacity to internalize the environmental and social cost of water. An increase of $0.0375 \mathrm{EUR} / \mathrm{m}^{3}$ in the present price of water for agriculture—optimal social price-internalizes a $65.67 \%$ of the environmental cost of water, whereas an increase of $0.0601 \mathrm{EUR} / \mathrm{m}^{3}$ guarantees the total internalization of the environmental cost, the maintenance of regional wealth, and a loss of 200 
jobs. A price increase of $0.0975 \mathrm{EUR} / \mathrm{m}^{3}$ would result in a variation of the regional GDP of $-0.31 \%$ (16.88 Million EUR). Employment would decrease around 400 jobs.

Non-monetary or social costs caused by irrigation are those inflicted on third parties or on the environment. In both cases, social costs originate from irrigators' use of valuable resources or from polluting the resource base. The former is generally associated with the opportunity cost, and provides an indication of the value of the water allocated to alternative users. Irrigation can affect the environment through its direct impact upon water resources, soils, biodiversity and landscapes, as well as its secondary impacts that arise from the intensification of agricultural production through the transformation of rain-fed land into irrigated land (EC, 2000).

Recent work shows that social costs are far from negligible, and provides a solid basis for urgent policy action. The list of regions or basins where problems related to excessive irrigated water use have been identified would be very long. Generally, resource overdraft is caused by a water demand, both urban and agricultural, quite above the sustainable rate, where the cost paid by users is generally below financial (monetary) recovery cost for surface water and fully or partially paid for groundwater. In south-eastern Spain, where some trading of water occurs especially for fruit, vegetables and greenhouse production, water cost is only around $2 \%$ of total cultivation costs. This implies that water demand will inevitably tend to go beyond sustainable renewable use, indicating that the private cost of water does not reflect the scarcity of the resource.

Regarding pollution by nutrients, the main polluter in Europe is the agriculture sector, including rain-fed and livestock farming. Irrigated agriculture contributes to the increasing nitrate contamination, due to over-fertilization. An important share of Phosphates pollution originates from urban sources. Examples of such direct effects have been found in the Adour-Garonne (France), in several Austrian regions such as the Marchfeld, the Pandofer plateau, and the Welser Heide and Eferding Becken areas, in a number of Spanish regions, mostly located along the Mediterranean coast and main river valleys, and in various nitrate vulnerable Greek zones such as Argolid, Kopas and the Thesaaly plain, where large irrigated areas are located (EC, 2000). Nevertheless, in most river basins the impact from livestock and rain-fed agriculture is higher than that from irrigation (e.g. in the Guadalquivir valley nitrates pressure generated by irrigated agriculture is around $22 \%$, against $52 \%$ and $22 \%$ generated by rain-fed agriculture and livestock, respectively).

As a consequence of the above-mentioned evidence of irrigation pressure on the environment, countries such as France or the Netherlands try to 'internalize costs' by using an 'ecotax' on water use by irrigators. This ecotax on water abstraction (mostly on groundwater, but also on surface water, e.g. in the case of France) tries to internalize environmental and social costs, but the level of environmental cost recovery is quite low as seen from the first reports presented by the EU member states reporting on WFD implementation. The Spanish government is debating whether to charge an ecotax on all water use (both surface water and groundwater) to contribute to global integrated resource management at the basin level and meet the 2010 deadline set by the WFD for implementation of measures including water pricing. Provisional estimates for this ecotax (EUR 1.00/1000 $\mathrm{m}^{3}$ ) make it a 'political contribution of users' rather than an environmental cost recovery charge.

The use of water pricing incentives such as the ecotax is opposed by some authors as Martinez and Albiac (2004) who show that nitrogen pollution is most efficiently abated by targeting either the source or the emissions, and very inefficiently by imposing levies on used water. Nevertheless, most models of irrigation water demand predict a significant reduction when a water tariff is imposed (e.g. $0.06 / \mathrm{m}^{3}$ in Aragon, Spain, reduces water demand by 50\%). This suggests that water and environmental policies must be closely linked and target the most pressing problems, be it water scarcity or nitrogen pollution. Still a further effort of empirical studies is required considering both short- and long-term farmer responses. In another paper these authors (Martínez and Albiac, 2006) find that water pricing, as advocated by the Water Framework Directive, is inefficient as a pollution abatement tool, and differentiating control measures by soil type enhances welfare, although welfare gains may be small. 
Numerous studies have shown that more efficient water use reduces agricultural pollution (Dinar and Letey, 1991; Weinberg et al., 1993; Calatrava and Garrido, 2001a). Yet, this does not imply that pollution control should be targeted with water pricing policies. Pollution control can be best performed within irrigation systems by providing precise water applications and monitoring.

More recently, Bartolini et al. (2007) studied five Italian irrigated farming systems: cereal, rice, fruit, vegetables and citrus. Their results show the diversity of irrigated systems and the different effects that water pricing policy may produce depending on the agricultural policy, market and technological scenarios. They also highlight a clear trade-off between socio-economic sustainability and environmental (water, nitrogen, pesticide) sustainability. Water pricing will have, in most cases, less impact than agricultural markets and policy scenarios, though it appears to be an effective instrument for water regulation in the least intensive irrigated systems considered. This emphasises the need for a differentiated application of the Water Framework Directive at the local level as well as a more careful balance of water conservation, agricultural policy and rural development objectives.

In the same vein, Seeman et al. (2007) analysed Italian (Apulia region) farmers' behaviour in different policy scenarios in terms of selected crops, irrigation technique and method, and adopted management practices with focus on farm management practices and water application efficiency. Irrigation water pricing, subsidies to adopt improved management levels, and taxation on the use of nitrogen fertilizer were examined. A trade-off emerged between the levels of nitrate leaching and net farmer's revenue more pronounced for nitrogen tax policies than for water pricing. The results obtained indicate that nitrate leaching can be reduced by about $40 \%$ with an associated net social cost of 269 /ha for the water pricing policy, $183 \mathrm{EUR} / \mathrm{ha}$ for the tax on fertilizer and 95 /ha for subsidies to high farm efficiency management.

Riesgo and Gómez-Limón (2006) concluded about the usefulness of a low water tariff (for example, $0.02 \mathrm{EUR} / \mathrm{m}^{3}$ ) that favours the implementation of the WFD environmental objectives (efficient water allocation and improvement of water ecosystems). In spite of the negative impacts caused by water pricing, therefore, a low price on water might still be regarded as necessary in order to make farmers conscious of the actual value of water to society, and the importance of using it properly. However, these authors conclude that water pricing should be developed in any case within a wider policy framework led by the CAP, which should attempt to avoid serious negative impacts on irrigated farming and guarantee the survival of rural areas (by minimising falls in farmers' income and the demand for agricultural labour).

\section{Water use incentives - Incentives for conservation and efficient water use}

According to the neoclassical definition of use externalities, most water problems in the European irrigation sector stem from situations where clear misalignments exist between farmers' private objectives and more general social objectives. The presence of divergences between private and social objectives is manifested by various trends. One is the widening of the divergence between farmers' low water marginal productivity in irrigated commodity production and the sum of the costs incurred by society for making the resources available to them (except for the case of high-value crops). Another is the confirmation that the water costs of competing users may be rising as a result of farmers' water use or polluting practices. Note that the manifestation of adverse incentives is perceived through time and not with snapshots. This implies that policy judgments should be preferably based on whether observed trends show improvements or are worsening.

A list of adverse incentives includes the following.

\section{Per hectare water charges}

Per hectare charges (flat rate) are perhaps the most adverse incentive affecting irrigation across OEDC countries. Very few irrigated districts relying on surface water have volumetric or other variable rate systems. The wide recognition of the need to change the tariff structures towards volumetric charges has not been accompanied by clear examples of policy implementation. To date, no rigorous evaluation has been made to measure the value of the efficiency losses resulting from the 
prevalence of flat rates. Montginoul and Rieu (2001) report that irrigators in Charente (France) are charged with two-part tariffs, but the fact that the variable rate is much lower than the marginal benefit of water use in the farms led the managers to impose water quotas in years of scarcity.

The comparison of water use levels of irrigators using surface water with those of farmers relying on groundwater may provide an indication of the effects of wrong signaling caused by flat rates. Hernández and Llamas (2001) show that groundwater users tend to use between $25 \%$ to $35 \%$ less than surface users. Yet, groundwater users with pressurized systems will obviously 'use' less than those on old surface water systems. In addition, return flows from upstream surface users may be used downstream, thus increasing the efficacy rates of surface water. All in all, an euro value of such water use differences is difficult to come by, but may be equivalent to a lower bound of 15.00 to 35.00/ha, with the most conservative assumptions.

Numerous obstacles hinder progress in replacing flat rates with volumetric rates. Among them is the fact that it may not be efficient to do so, under a broad range of realistic situations. Work done by Tsur and Dinar (1997) illustrates how the efficiency gains may not justify the costs of restructuring tariffs. Chakravorty and Roumasset (1991) and Hafi et al. (2001) show that volumetric charges would have wealth re-distributional effects in large districts with network losses. Another relevant obstacle is the lack of appropriate water- metering devices in many European irrigation districts.

Investment in irrigation technologies has ambiguous effects in general policy evaluations. Negative effects result from the fact that changes in technology may induce new crop patterns and increase total water consumption. García Mollá (2002) shows that drip irrigation technologies have been subsidized in the region of Valencia in Spain but, contrary to general belief, irrigators have not reduced application rates. Similar behaviour has been observed in the Guadalquivir river basin, in the sense that the adoption of drip irrigation has encouraged the planting of new crops (orchards, vegetables, etc.) that are more water-demanding than the preceding ones (Berbel, 2005).

\section{Inelasticity of demand}

The number of studies showing that irrigators' water demand is highly inelastic in the short term, at least at low prices, is at odds with the fact that there are large differences in water consumption and application rates among irrigators and water districts. This means that differences are not governed by prices but by other factors. Response to price increases is not continuous as there is an optimum supply of water for each crop and the water production function implies that the optimum is not sensitive to price increases until a break-even point is surpassed, when a new crop is introduced or farmers simply go for rain-fed crops. One would assume that if a set of irrigators seem to operate with low consumption rates, then another operating under similar conditions could be flexible enough to reduce its consumption. Whether it is a change of water price or a reallocation of water rights, the conclusion would be that the latter irrigators can and should reduce their consumption, following a relatively elastic water demand curve.

Before delving into this paradox, García Mollá (2002) suggests that water should be thought of as a productive input, whose demand elasticity depends on three factors: a) the elasticity of substitution of water for other inputs, b) the price elasticity of demand for the good being produced and c) the share of irrigators' total costs represented by water costs. The practical application of these principles is that water cannot be substituted by other inputs, except for large-water demanding crops like rice which are grown with little use of capital.

Work by García Mollá (2002), perhaps the most detailed analysis ever done in Spain to explain water use differences across all districts in the Valencia region, shows that water use variability is largely explained by three factors, namely, the type and institutional arrangement of districts, the origin of the used water and the type of pricing scheme. García Mollá's results suggest that traditional districts supported by state projects combined with 'two-part tariff systems' exhibit the lowest consumption levels. They also suggest that all districts using groundwater exclusively or in combination with surface water tend to consume more than those that rely exclusively on surface water resources, indicating perhaps unsustainable use. 
Bontemps et al. (2003) show that water demand in southern France is inelastic for low available volumes, and depends crucially on the weather conditions. Rieu (2005) shows that, although demand in Charente is elastic, local authorities have established quotas to avoid the negative effects on farm income. Overall, pricing policies in France seem to be driven primarily by the objective to ensure cost recovery and agency's budget balance, although this is achieved by a great variety of pricing mechanisms (Rieu, 2005). Dono and Severini (2001) add further evidence from southern Italy to the inelasticity hypothesis, and suggest that water demand turns increasingly inelastic as water charges increase, as the crops that may be able to pay higher prices are mainly high-value vegetables and fruits, which can support high water price increases.

Finally, Massarutto (2003) concludes that the demand inelasticity hypothesis should be framed in relation to the concept of 'exit price.' He claims that the effects on water demand are due to the fact that if water prices are below the exit threshold, they result in demand reductions caused by marginal adaptation of irrigation demand to price variations. Water demand elasticity is always very small, especially once the most obvious water saving techniques have already been implemented. Above the exit price, water demand is brought to zero because farmers do not cover the input costs and they are better-off not using the water.

\section{Agricultural policies interacting with water pricing policies}

Examples of crops, across the European Union, with high water requirements supported by Common Agricultural Policy (CAP) programmes were numerous. Maize is considered a water demanding crop in temperate countries, and its EU growers were until 2003 entitled to a direct subsidy of 54.00/ton of yield, which usually exceeds $10 \mathrm{t} / \mathrm{ha}$. Since the CAP direct subsidies were defined to deliver equivalent levels of income support to all cereal, oilseeds and protein crops, they favour crops such as corn, rice, cotton or tobacco that demand much more water than oilseed crops such as sunflower or colza. With decoupling, this inconsistency has been eliminated, and farmers' use of water will not be driven by subsidy differences across crops.

Between 1973 and 1988, agricultural water use in France grew by 43\%, largely due to generous public programmes which provided subsidies to farmers installing irrigation equipment, as well as guaranteeing generally low agricultural water prices. Most of the increase was used in corn production. This trend was reinforced after the 1992 CAP reform replaced production subsidies by per hectare direct payments, as a result of the higher compensatory payments given to irrigated acreage than to non-irrigated acreage (Rainelli and Vermersch, 1998; Dubois de la Sablonière, 1997).

EU agricultural policy 'Agenda 2000' aimed at supporting a multifunctional, sustainable and competitive agriculture. It was based on the establishment of production-related direct aid payments and gave a prominent role to agri-environmental instruments to support farmers' income. In June 2003, the EU decided to replace, from 2006 onward, most of the direct aid with a single farm payment scheme that is not linked to production. Beneficiaries will be obliged to accomplish certain environmental and food safety requirements, being those almost identical for irrigation and rain-fed farms. The EU Commission recognized, within the launching of the 'CAP's Health Check', that a new CAP should achieve climate change and water management objectives by means of cross compliance. The Commission has proposed that Compliance rules should be changed to include among other requirements: "standards on protection of water against pollution and run-off (the new standard "establishment of buffer strips along water courses"), and where use of water for irrigation be subject to compliance with authorization..

Work done by Calatrava and Garrido (2001b) shows that CAP's Agenda 2000 tended to increase irrigators' water demand in the Spanish region of Andalusia with respect to the pre-2000 situation, which was confirmed in the case of olive oils and vineyards. These authors show that the price support delivered to cotton producers in the region is largely responsible for the large benefit of water in the region. Pressure on water demand by farmers in the region has been on the rise, although recent changes in the Common Market Organization for cotton may have an inverse effect, as cotton support has been largely reduced. Many authors have established a connection between farm subsidies and irrigation water demand in Spain (Sumpsi et al., 1998; Gomez-Limón et al., 2002; Arriaza et al., 
2003; Iglesias et al., 2004). Their results show that, indeed, the elimination of farm subsidies has a larger impact on the farmers' welfare than the rise of water prices. When EU farm subsidies become completely decoupled from production in 2012, the economics of irrigation will be more guided by the relative productivity of crops and water accessibility than by relative farm subsidies granted to the crops.

Mejias et al. (2004) add further evidence to the water demand inelasticity hypothesis. In addition, they show that the EU policy based on full decoupling will likely reduce the income losses resulting from WFD's increased water tariffs, at least in Andalusia (Spain). Since 2003, direct payments are almost fully decoupled from production across EU member states. This means that farmers, in most MS, are entitled to a subsidy based on the direct payments received during a reference period (years 2000, 2001 and 2002), irrespectively of their cropping patterns and farm-size thereafter. Other farm policy reforms affected the sugar, cotton, olive and wine sectors, making the support mechanisms less coupled with production, albeit not entirely decoupled. In the case of Spain, these farm policy reforms have had marked impacts in irrigated agriculture, especially in the regions where fruits and vegetables were less important in terms of value and acreage. While in the Mediterranean provinces fruits and vegetables consume most water available for irrigation, in the mainland provinces cereals, protein and forage crops, sugar beets, potato and a few fruit species have been the primary irrigated crops.

Garrido and Varela-Ortega (2008) have reported the gradual but steady changes of irrigated land allocation occurred in Spain since the 2003 CAP reform. The major and most significant changes were that more irrigated land resources have been allocated to vineyards, olive trees and citrus (especially in Andalusia), and less irrigated lands allocated to water-consuming crops such as maize and other reformed sectors, including sugar beet, cotton and tobacco.

The definition and components of the costs of supplying water for irrigation

\section{Categories of cost}

There is no agreement in setting common criterion to define and evaluate irrigation cost items. In this section, we review two approaches: the EU's WFD and that by Malik (2008).

The WFD distinguishes between financial, environmental and resource costs of water services. Water services are defined as "all services, which provide, for households, public institutions or any economic activity: (a) Abstraction, impoundment, storage, treatment and distribution of surface water or groundwater, (b) Wastewater collection and treatment facilities, which subsequently discharge into surface water." (Art.2, definition 38). Water use means water services together with any other activity having a significant impact on the status of water. Note that the difference is subtle and crucial, not because pricing principles should be applied differently, but because pricing policies should be applied with regard to and compared to the service costs. In general, water users encompass water service beneficiaries. Irrigation is, of course, a water service beneficiary, but agriculture in general may be a water user. This report focuses only on irrigation as a water service beneficiary.

The WFD identifies three categories of irrigation costs (EC, 2003) (see figure 1):

- Financial costs (i.e. full supply costs): Include the costs of providing and administering these services. They include all operation and maintenance costs, and capital costs (principal and interest payment), and return on equity where appropriate).

- Resource costs: Represents the costs of foregone opportunities which other uses suffer due to the depletion of the resource beyond its natural rate of recharge or recovery (e.g. linked to the overabstraction of groundwater). 
- Environmental costs: Represent the costs of damage that water uses impose on the environment and ecosystems and those who use the environment (e.g. a reduction in the ecological quality of aquatic ecosystems or the salinisation and degradation of productive soils).

Figure 1. WFD Water service costs definition

\section{Box 1 - What are the different types of costs mentioned in the Directive?}

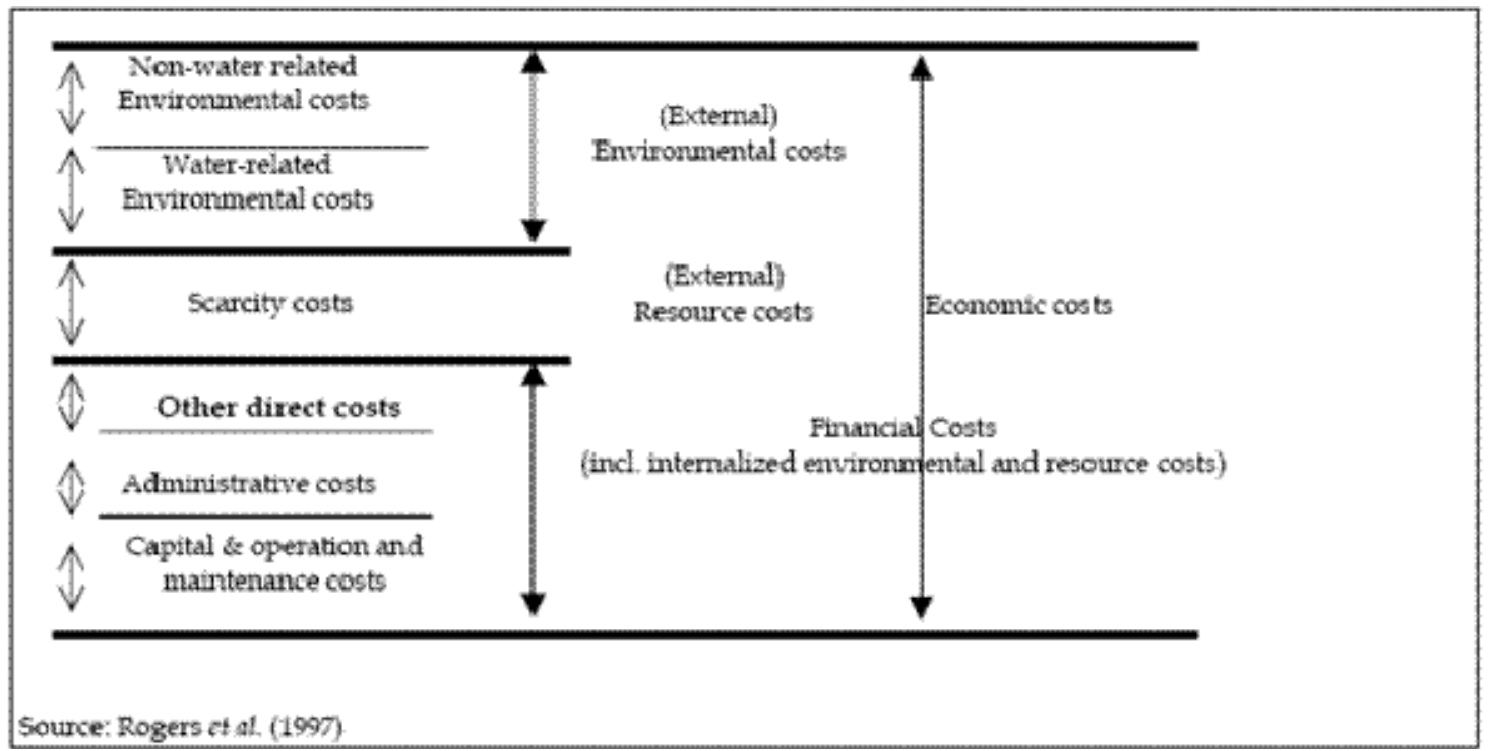

Source: Wateco (EC, 2003).

\section{Methodologies to evaluate capital costs}

There are numerous ways to define and evaluate the capital costs of irrigation infrastructure. In the case of the EU, there the Wateco guidelines (EC, 2003) define three categories:

- New investments. Cost of new investment expenditures and associated costs (e.g. site preparation costs, start-up costs and legal fees). In the case of projections, cost of capital should be expressed in Annual Equivalent Cost, using a standard annualisation method.

- Depreciation. Annualised cost of replacing existing assets in future. However, guidelines offer a choice of several methods to value of existing assets:

- Historical value: assets evaluated at the price they were originally purchased. Because of inflation, this value often bears no relation with what it would actually cost today to replace those assets.

- Current value is the historical value multiplied by an inflation index.

- Replacement value method estimates the present value of an asset from the current cost of replacing it for an identical service level.

- Opportunity cost of capital, i.e. an estimate of the rate of return that can be earned on alternative investments. Although guidelines find acceptable the use of non-private expected rates of return, they recommend that a non-zero rate should be use. Capital subsidies must be taken into account. 


\section{Measuring irrigation water subsidies}

This section attempts to delineate various definitions that have been proposed to measure subsidies to irrigation subsidies. Among these, we will review Malik (2008) and the Wateco Guidelines (EC, 2003).

Malik (2008) evaluated two approaches:

- One based on the comparison between farmers' water value and water total costs. Farmers' water value can be based on:

- Willingness-to-pay

- Water productivity.

- One based on the comparison between farmers' total chargers and water total costs.

- Wateco Guidelines (EC, 2003) suggest that water subsidies should be based on, equally to Malik's second approach, the difference between farmers' total payments and total water service costs, with a detailed definition of financial (capital) costs, including a return to capital.

The notion of 'building block' considered in the summary of the 2006 December OECD meeting on Measuring Support to Water in Agriculture and Sustainable Water Management is an alternative approach to reflect on farmers' water subsidies. The premise is that the different components of water costs have entirely different characteristics, domain and time frame. Furthermore, very often the tariffs or chargers paid by farmers result from a sum of components that are levied by different institutions (the ministry, the basin agencies, the irrigation district, or the water user association). On the most complex water systems farmers water payments result from a summation of items, each connected to a different institution, which in turn incurs O\&M and capital costs.

The above suggests that there exists a continuum between very narrowly defined subsidies and broadly defined subsidies:

a) Very narrowly defined subsidies: direct O\&M costs incurred by the Ministry or agencies that are not covered by the farmers. This may include energy costs, personnel costs or repairing and maintenance costs of districts' infrastructure. [Note that this definition does not apply to cases in which the O\&M costs are not incurred by mismanagement or lack of public resources, which is the case of Mexico in the initial steps of the ITM process, and Spain with old and traditional districts.]

b) Narrowly defined subsidies: preferential financing schemes to create new, or improve already functioning, irrigation districts, which involve low interest rates or inadequate annualisation calculations.

c) Broadly defined subsidies: points a) and b) applied to general infrastructures, servicing multiple users, resulting in cross-subsidisation between sectors or the state assuming the gaps (Malik elaborates the problems encountered with multiple-purpose facilities).

d) Very broadly defined subsidies: point c) plus nil or low returns to capital investments.

e) Economic inefficiency: use of water for irrigation that has a higher economic value for other users with access to the same water.

\section{Country case studies: France, Greece, Italy, Portugal, Spain and Mexico}

Table 1 shows the basic figures for irrigation in the six studied countries. 
Table 1. Water sector and irrigation basic figures for studied countries

\begin{tabular}{|c|c|c|c|c|c|c|}
\hline & France & Greece & Italy & Mexico & Portugal & Spain \\
\hline $\begin{array}{l}\text { Total population, } \\
2005\end{array}$ & 60496000 & 11120000 & 58093000 & 107029000 & 10495000 & 43064000 \\
\hline $\begin{array}{l}\text { Average } \\
\text { precipitation 1960- } \\
\text { 2007, } \\
\text { AQUASTAT } \\
\text { (mm/year) }\end{array}$ & 867 & 652 & 832 & 752 & 854 & 636 \\
\hline $\begin{array}{l}\text { Total renewable } \\
\text { water resources, } \\
\text { AQUASTAT } \\
\left(\mathrm{Km}^{3} / \text { year) }\right. \\
\end{array}$ & 203.7 & 74.25 & 191.3 & 457.22 & 68.7 & 111.5 \\
\hline $\begin{array}{l}\text { Total renewable } \\
\text { water resources } \\
\text { AQUASTAT } \\
\left(\mathrm{m}^{3} / \text { capita }\right)\end{array}$ & 3367 & 6677 & 3293 & 4272 & 6546 & 2589 \\
\hline $\begin{array}{l}\text { Total water } \\
\text { withdrawal, 2000, } \\
\text { AQUASTAT } \\
\left(\mathrm{Km}^{3} / / \mathrm{yr}\right)\end{array}$ & 39.96 & 7.76 & 44.37 & 78.22 & $8.44 * *$ & 35.63 \\
\hline $\begin{array}{l}\text { Total water } \\
\text { withdrawal per } \\
\text { capita } \\
\left(\mathrm{m}^{3} / \text { inhab/yr }\right)\end{array}$ & 668.72 & 702.39 & 766.59 & 759.82 & 1089.92 & 856.28 \\
\hline $\begin{array}{l}\text { Agricultural water } \\
\text { withdrawal as \% of } \\
\text { total water } \\
\text { withdrawal, } 2000 \text {, } \\
\text { AQUASTAT }\end{array}$ & 10 & 81 & 45 & 77 & $61 * *$ & 68 \\
\hline $\begin{array}{l}\text { Domestic water } \\
\text { withdrawal as \% of } \\
\text { total withdrawal, } \\
2000 \text {, } \\
\text { AQUASTAT }\end{array}$ & 16 & 16 & 18 & 17 & $7 * *$ & 13 \\
\hline $\begin{array}{l}\text { Industrial water } \\
\text { withdrawal as \% of } \\
\text { total water } \\
\text { withdrawal, 2000, } \\
\text { AQUASTAT }\end{array}$ & 74 & 3 & 37 & 6 & $18 * *$ & 19 \\
\hline $\begin{array}{l}\text { Arable and } \\
\text { permanent crops, } \\
\text { 2005, FAOSTAT } \\
\text { (ha) }\end{array}$ & 19635000 & 3759000 & 10283000 & 27600000 & 1911000 & 18630000 \\
\hline $\begin{array}{l}\text { Area equipped for } \\
\text { irrigation, } 2005 \text {, } \\
\text { AQUASTAT (ha) }\end{array}$ & 2706480 & 1593780 & 3972670 & 6256030 & 616970 & 3765130 \\
\hline $\begin{array}{l}\text { Area actually } \\
\text { irrigated, 2005, } \\
\text { AQUASTAT (ha)* }\end{array}$ & 1696370 & 1312650 & 2613420 & 5505310 & 453540 & 3364530 \\
\hline $\begin{array}{l}\% \text { of area equipped } \\
\text { for irrigation that is } \\
\text { actually irrigated }\end{array}$ & 63 & 82 & 66 & 88 & 74 & 89 \\
\hline $\begin{array}{l}\% \text { of irrigated to } \\
\text { arable land }\end{array}$ & 9 & 35 & 25 & 20 & 24 & 18 \\
\hline
\end{tabular}

Figures compiled from FAO's databases unless otherwise stated.

(*) Figure for Mexico corresponds to 1997; (**) Figure for 2002 from the OECD Statistical extracts. 


\section{France}

Irrigation in France has tripled in the 30-year period between 1970-2000, reaching about 1.696 million hectares (sources vary between FAO, as shown in Table 1, and Rieu (2005) reporting 1.575 for 2000 based on data from CGGREF, 2005). However, farmland considered potentially irrigated should add another million hectares. According to CGGREF (2005), 71\% of farms and 85\% of the effectively irrigated area are currently equipped with volumetric metering devices. The French Water Law of 2006 imposes the equipment of volumetric metering devices, defines the types of charges that can be levied for water consumption by the 6 water agencies, the conditions under which users can abstract surface and groundwater resources, the procedure by which the State (Préfets départementaux, who are the local State representatives) grants the use rights. In certain departments, the use rights are granted annually by the Préfets, but in most of them they are granted for more than one year, the former criterion becoming less and less used in France. However any authorization given for water extraction can be temporarily or permanently revoked or reduced by the Préfets in case of water scarcity, as required to ensure adequate environmental protection and/or domestic water consumption. Regulations are also more stringent in some areas qualified nationally as suffering of chronic water shortage. Another change introduced in France by the enactment of the last Water Law is the possibility for the Préfets to establish zones in which the authorization for water extraction is given to a single body who will manage it between all irrigators. The French Water Law establishes a common framework for all agencies to design the charges.

Basin authorities (Agences de l'eau), where most users and stakeholders are represented, can exercise considerable scope in water planning and management and in setting water charges. Before 2006, water charges in France have two components: a basin component (based on the average volume abstracted) and a consumption component (levied on the difference between abstractions and return flows). The criteria used to set charges varied substantially across basins before the enactment of the 2006 Water Law, and mostly depend on characteristics such as the probability of drought, the type of user, capital costs, ownership, and other basin characteristics (Duchein 1997). Charges cover O\&M and part of capital costs (Chohin-Kuper et al. 2003). Another element of variation is the differing access to water resources of French irrigators. Rieu (2005, citing official sources of year $2000^{2}$ ) reports that $23.6 \%$ of the acreage is serviced through collective organisations, $56.4 \%$ is serviced by direct abstractions of the irrigators themselves and $20 \%$ by both collective and individual means. Increasingly farmers belonging to collective organisations have private wells that are used to complement the supplies of their organisation.

Water basin authorities charge all users, independently of the type of supply, a water tax inspired in the polluter pays principle (Rieu, 2005). Table 2 reports the taxes and the abstracted volumes. Note that the lowest charges are found in those basins with the largest abstracted volumes (Adour Garonne, Loire Bretagne and Rhone-Mediterranée).

Table 2. Water taxes for irrigation charged in the Agences de l'Eau

\begin{tabular}{|l|c|c|c|}
\hline $\begin{array}{l}\text { Water basin } \\
\text { authorities }\end{array}$ & $\begin{array}{c}\text { Average Tax } \\
\left(\mathbf{2 0 0 2}, \mathbf{~ m}^{\mathbf{3}}\right)\end{array}$ & $\begin{array}{c}\text { Minimum-maximum } \\
\mathbf{( 2 0 0 3 - 2 0 0 6 , / \mathbf { m } ^ { \mathbf { 3 } } )}\end{array}$ & $\begin{array}{c}\text { Abstracted volume } \\
\left(\mathbf{m i l l i o n} \mathbf{~ m}^{\mathbf{3}} \mathbf{2 0 0 2}\right)\end{array}$ \\
\hline Adour Garonne & 0.0047 & $0.0026-0.0057$ & 758 \\
\hline Artois Picardie & 0.0134 & $0.0012-0-0609$ & 15 \\
\hline Loire Bretagne & 0.0066 & $0.0044-0.0175$ & 499 \\
\hline Rhine Meuse & 0.0014 & $0.0013-0.0015$ & 77 \\
\hline Rhône Méditerranée & 0.0015 & $0-0.0027$ & 1643 \\
\hline Seine Normandie & 0.0171 & $0.0051-0.0192$ & 95 \\
\hline
\end{tabular}

Source: Rieu (2005), using data from the Agences de l'Eau.

2. Service Central des Études et Enquêtess Statistiques- recensement agricole, 2000. 
Farmers serviced partially or totally through collective organisations are generally charged a twopart or binomial tariff. The Associations Syndicales Autorisées (ASA) and the Sociétés d'Aménagement Rural (SAR) charge average volumetric tariffs of 0.03-0.053 per $\mathrm{m}^{3}$ (ChohinKuper et al. 2003). Some SARs also have optional binomial tariffs (40 /ha and 0.07 per $\mathrm{m}^{3}$, or 25 /ha and $0.17 / \mathrm{m}^{3}$ ). Others, like the SAR in the Languedoc Roussillon Region (BRL), have pricing schemes that discourage use above certain thresholds. Farmers pay a binomial tariff, comprising both a fixed per hectare and a volumetric charge. Average water charges for irrigation range between 0.085 and 0.30 per $\mathrm{m}^{3}$ (Montginoul 1997). In areas where per hectare charges are paid, average tariff is 104 per hectare (Chohin-Kuper et al, 2003).

In-depth analysis of the tariff structures in Charente River shows remarkable differences in structure and levels (Rieu, 2005). Montginoul and Rieu (2001) reported that farmers in Charente district paid 6.9 /ha plus $0.0035^{3}$. The study of CEMAGREF (2004, cited by Rieu, 2005) including 75 associations reports an average price of $0.11 / \mathrm{m}^{3}$, and a $95 \%$ interval between 0.09 and $0.12 / \mathrm{m}^{3}$. According to CGGREF (2005, citing also the CEMAGREF 2004 study), this average price paid by farmers cover $94.8 \%$ of the average cost of water (estimated in $0.115 / \mathrm{m}^{3}$, not including neither environmental nor resource costs), while only $5.2 \%$ is born by public funds. The part of the average water cost that is covered by the price paid by farmers is composed by a $52 \%$ capital cost, a $38 \%$ operation cost and a $10 \%$ maintenance cost. Table 3 includes examples of tariffication schemes in the Charente.

Table 3. Water tariffs in collective irrigation schemes in the Charente

\begin{tabular}{|l|c|c|c|}
\hline Water tariff structure & Fixed ( /ha) & Variable $\left(\mathbf{~ m}^{\mathbf{3}}\right)$ & $\begin{array}{c}\text { \% of sampled } \\
\text { associations }\end{array}$ \\
\hline Binomial (ha+Vol) & 81 & 0.06 & 33 \\
\hline Binomial (flow+Vol) & 38 & 0.06 & 8 \\
\hline Flat rate (ha) & 198 & - & 23 \\
\hline Volumetric & - & 0.10 & 11 \\
\hline
\end{tabular}

Source: Rieu (2005), using data from the Agences de l'Eau.

CGGREF (2005) revises the existing studies on irrigation water charges in France to conclude that fixed rates are still predominant and that there are significant differences in the cost of water born by farmers between basins and within each basin. These differences are greater for volumetric rates than for flat rates. Irrigation costs are calculated to be on average $20 \%$ of total production costs for the main crops in the country. They also calculate that fees paid by farmers to basin authorities are a small part of the total of irrigation ( 2 to $8 \%$ ).

In general, water charges across all irrigation units in France have been increasing over time, due to three basic reasons. The first is the 1992 Water Code, which sought to broaden the revenue base for water supply companies in order to ensure their financial stability. Second, there has been a large increase in irrigated acreage across France, adding more pressure on several basins during summer or drought periods. Third, pollution is now considered as another "use" of public waterways and water bodies, so that water authorities can sometimes justify charging "resource-based" prices which can be added to other accounting and/or capital cost components. Farmers only pay pollution fees for water used in cattle production but not in crop production. Rieu's (2005) comprehensive review of water pricing policies in France shows that policies have been geared towards cost recovery objectives. Yet, there are large capital costs differences across basins and irrigated areas, creating a large range of capital costs recovery, between $15 \%$ and $60 \%$. The pricing systems vary from 'average cost' to 'marginal cost', which are jointly used with quotas systems. 
Hardly any data on cost recovery for irrigation in France has been found. The summary analysis performed by the French Government for the European Commission based on the basin reports for article 5 of the WFD, which can be found on the web page http://www.eaufrance.fr, only gives data on revenues, expenditure and cost recovery level for drinking water distribution and collective sewerage services in the different French basins. According to this source, average water price for drinking water in France is $2.71 / \mathrm{m}^{3}$. Revenues collected by the water agencies cover $140 \%$ of the O\&M cost and $91 \%$ of O\&M plus amortisation costs. O\&M costs are covered by water fees in all basins, whereas the sum of O\&M and amortisation costs is not fully recovered in any basin. Regarding investment costs, the revenues collected in France through water prices accounts for almost $85 \%$ of total investment costs in drinking water supply and sewerage infrastructures.

In the case of irrigation, very little information has been found detailing cost-recovery rates. Only capital investments and subsidisation rates could be identified for three basins, reported in Table 4. CEMAGREF (2002) is the most commonly cited source for the analysis of cost-recovery rates. It indicates that irrigation in SARs and ASAs has full O\&M cost-recovery rates, whereas capital costs' recovery is only $40 \%$ (cited by Plan Bleu, 2007).

Three significant cases in France about infrastructure's tariff structure are provided by the Société du canal de Provence (SAR located in South-east France), the SAR BRL, the company for the development of the Languedoc-Rousillon Region and the Neste Canal of the Company for the Development of the Cotoux de Gascoigne Region (SAR), the three of which different users including irrigation agriculture. Table 5 summarises the main rate schemes for irrigation of these important Southern French infrastructures.

Table 4. Capital investments and subsidisation in irrigation in three French basins

\begin{tabular}{|l|c|c|c|}
\hline Basins & $\begin{array}{c}\text { Investment costs in irrigation } \\
\text { (mill /year) }\end{array}$ & $\begin{array}{c}\text { Subsidies } \\
\text { to investment }\end{array}$ & Subsidy rate \\
\hline Rhône Méditerranée & 42 & 29.5 & $70.2 \%$ \\
\hline Adour-Garonne & 37.5 & 16.3 & $43.5 \%$ \\
\hline Guadaloupe & 19.2 & 17.2 & $89.6 \%$ \\
\hline
\end{tabular}

Source: Comité du Bassin Rhône-méditerranée (2005), Comité du Bassin Adour Garonne (2005) and Comité du Bassin de la Guadeloupe (2005).

Table 5. Specific irrigation tariff schemes in three important canals in southern France

\begin{tabular}{|c|c|c|}
\hline & Rates setting criterions & Ranges of tariffs \\
\hline $\begin{array}{l}\text { Société du } \\
\text { Canal de } \\
\text { Provence }\end{array}$ & $\begin{array}{l}\text { - Long-term supply-cost } \\
\text { - Proportional share of the value of water } \\
\text { and O\&M costs } \\
\text { - A negotiated component } \\
\text { - Peaked pricing }\end{array}$ & $\begin{array}{l}\text { - Upstream command area: } 14 / \mathrm{ha}+0.09 / \mathrm{m}^{3} \\
\text { - Intermediate command area: } 12 / \mathrm{ha}+ \\
0.07 / \mathrm{m}^{3} \text {. } \\
\text { - Coastal command area: } 9 / \mathrm{ha}+0.04 / \mathrm{m}^{3}\end{array}$ \\
\hline $\begin{array}{l}\text { BRL } \\
\text { Languedoc- } \\
\text { Rousillon } \\
\text { Region }\end{array}$ & $\begin{array}{l}\text { - Under-utilised infrastructure } \\
\text { - Optional charge schemes for farmers } \\
\text { - Considers irrigation techniques, } \\
\text { irrigated crops and types of uses }\end{array}$ & $\begin{array}{l}\text { - Flow regime for frequent users: } 54 \text { /ha+ } \\
0.076 / \mathrm{m}^{3} \\
\text { - Volumetric tariff for occasional users: } \\
36 / \mathrm{ha}+0.184 / \mathrm{m}^{3}\end{array}$ \\
\hline $\begin{array}{l}\text { Canal de } \\
\text { Neste, } \\
\text { Cotoux de } \\
\text { Gascoigne } \\
\text { (SAR) }\end{array}$ & $\begin{array}{l}\text { - Based on allocated quotas to farmers } \\
\text { - Penalty rates for over-use } \\
\text { - Bloc-rate system } \\
\text { - Referred to a parameter, p, based in } \\
\text { SAR's costs and farmers' costs }\end{array}$ & $\begin{array}{l}\text { - Fixed part: } 60 \mathrm{xp}=54 \text { for a subscribed flow } \\
(1 / \mathrm{s}) \\
\text { - Metering fee }(1 / \mathrm{s})=40 \mathrm{xp}=36 \\
\text { - Overuse penalty }\left(\mathrm{m}^{3}=120 \mathrm{xp}=108.1 \quad \text { (with }\right. \\
\mathrm{p}=0.901 \text { in } 2005)\end{array}$ \\
\hline
\end{tabular}

Source: Rieu (2005). 


\section{Greece}

Greece is relatively well endowed with water resources. According to the Aquastat FAO database, water use in Greece is only a small fraction, approximately $10 \%$ of total renewable resources. Total water consumption amounts to $7,907 \mathrm{Hm}^{3}$ according to the Greek Government (MEPPPW, 2008). The main user is the agricultural sector. The contribution of agriculture to Greece's GNP is one of the highest proportions in Europe. Greece has about 1.31 million hectares of irrigated land, which represents $35 \%$ of its total arable area and almost $10 \%$ of the country's total land surface. Irrigated farming accounts for around $81 \%$ of the nation's total water consumption, while domestic uses account for a $16 \%$ and industrial uses for a $2 \%$.

Irrigated acreage has increased by about $65 \%$ in the last 20 years, as a result of a strong political commitment to increase both agricultural production and farm income in rural areas. It is also the result of private initiatives, which currently represent about $60 \%$ of total Greek irrigated acreage, mostly equipped with sprinkler or drip technologies. The remaining $40 \%$ of the total irrigated acreage $(532,000$ hectares) is composed of co-operative irrigation projects, resulting from the joining of the Local Land Improvement Boards (TOEV) and the National Land Improvement General Boards (GOEV).

TOEVs manage water allocation, collect farmers' fees, and manage collective facilities. GOEVs are semi-governmental organizations that finance works affecting more than one TOEV. Public projects are mainly equipped with modern irrigation technologies, although $41 \%$ of the irrigated area still uses gravity irrigation systems. The construction of irrigation projects comes under the responsibility of rural regional authorities. Therefore, all government assistance given for irrigation facilities is aimed not only at economic objectives, but also at environmental consumption and social objectives as well.

The Greek water economy is presently approaching "maturity", and there are few new opportunities to expand irrigation supplies. Irrigation water demand has been slowly increasing in the past decades, and the tendency is to stabilize (Margat, 2002). Public investment in reclamation projects have decreased about $32 \%$ since the 1970s. Although there are some on-going initiatives which combine environmental objectives with better water and irrigation management, no significant effort has yet been made to make farmers pay for the important rehabilitation and maintenance costs which will be needed in the future. Both the challenging natural conditions of Greece and the relative economic importance of its agricultural sector are factors which explain the delay in implementing water pricing reforms in this sector. Of equal importance is the widely held perception in Greece that water supply projects are multi-purpose facilities that contribute towards social progress, environmental conservation and protection.

According to Lekakis (1998), access to water resources has not yet been fully regulated, and the organization of the water management agencies and water suppliers is essentially governed by the civil code. This institutional framework, together with the remarkable hydrologic complexity of the country, explains why it is not possible to identify any common trends in Greek agricultural water pricing systems. Though, being Greece an EU member state, a common set up will have to be in place by 2010 for all irrigators. Another factor which contributes to this heterogeneity is the fact that more than $40 \%$ of agricultural water demand is supplied by groundwater resources, so that water fees are totally dependant on extraction costs, including fuel or electricity consumption. TOEVs set fees to cover administration, maintenance and operation costs of their collective facilities. On average, the revenues collected with these charges represented about $60 \%$ of TOEVs' total expenses in 1994, the rest being covered by the State. Lekakis (1998) also provides an estimated range of pumping costs of 41 to 192 per hectare. Charges paid to TOEVs cover only part of O\&M and nothing of capital costs, while individual irrigators pay both of them (Chohin-Kuper et al, 2003; Massarutto, 2003). According to Chohin-Kuper et al. (2002), agricultural water tariffs paid by farmers are in the range 73-190 /ha, while Massarutto (2003) gives similar figures (90 to 210 /ha for flat rates and 0.02 to $0.7 / \mathrm{m}^{3}$ for less frequent volumetric rates). 
Chartzaloulakis and Angelakis (2001) provides with examples for the Island of Crete, where water resources come from groundwater and farmers pay volumetric rate tariffs: Large irrigation districts pay $0.0457-0.052 / \mathrm{m}^{3}$, Community water projects pay on the $0.050-0.065 / \mathrm{m}^{3}$ range and private water projects pay $0.14-0.23 / \mathrm{m}^{3}$.

However, since December 2003, a new legislative and institutional framework has been put into force in Greece. It consists of Law 3199/2003 on the "protection and the sustainable management of the water resources" that transposes the EU Water Framework 2000/60/EC Directive (WFD) into the national legislation. This law emphasises the environmental aspects of water management, the importance of water management at the river basin level and of total cost recovery pricing and the "polluter pays principle". It also establishes the creation of Regional Water Directories and Councils for each one of the Water Regions or River Basin Districts. These will be supervised by the National Water Agency, that belongs to the Ministry of Environment, Physical Planning and Public Works (MEPPPW) and its main objectives will be to coordinate water policy activities and implement specific Programmes of Measures and Action Plans for achieving the environmental objectives of the WFD for each RBD (MEPPPW, 2008).

The following tables (Tables 6 and 7) comprise the official data for water consumption, cost of water services and level of full cost recovery for the 14 water regions Greece is divided in. These tables have been elaborated from the information in The Greek Final Report for article 5 of the Water Framework Directive (MEPPPW, 2008). Some corrections have been made to typographical errors in the original text. The different categories of costs have been determined as follows:

- The financial cost (i.e. full supply cost) has been taken from the annual financial reports of the companies providing water for both domestic (DEYA) and irrigation (TOEB) purposes.

- The resource cost was only calculated for those four water regions where the demand-supply water balance is negative, i.e. in Aegean Islands, East Sterea Ellada, East Peloponnesos and Thessaly. The resource cost was approximated considering the best water source alternative in each area (the cost of water desalination, the cost of recycled water, etc.)

- The environmental cost has been obtained using a "Benefits Transfer" of values obtained in a large number of valuation studies which applied stated preferences methods. This technique allows for adjusting the values obtained in these studies using relevant socio-economic data for the areas where the studies were performed and the areas where the values are to be "transferred".

The level of cost recovery has been calculated as the percentage of the total cost of water services that are recovered by the collected revenues from water services. It should be pointed out that the revenue figures used by the Greek Government include both tariffs set by water companies to water users and to water polluters. Furthermore, Common Agricultural Policy subsides attributable to irrigated agriculture are included as a cost in the calculation of cost recovery for agricultural water users. We have calculated the level of cost recovery both including and excluding agricultural subsidies (table 7). The average cost recovery level in Greece is $64.66 \%$ for domestic and industrial uses and $54 \%$ for agricultural users. Total full cost recovery level is $63.75 \%$ for all uses. With a couple of notable exceptions, water companies do not cover their costs. Furthermore, not even financial costs (i.e. full supply costs) are covered with the collected revenues.

Based on the data in MEPPPW (2008), average water tariffs paid have been calculated dividing the total amount of revenues paid by farmers and the amount of water used in each water region (Table 6). These range from an average $0.011 / \mathrm{m}^{3}$ in Central Macedonia to $0.1 / \mathrm{m}^{3}$ in Crete, and are quite similar to those found in the literature. 
Table 6. Water demand and full costs of water services in Greece

\begin{tabular}{|c|c|c|c|c|c|c|c|c|c|}
\hline \multirow[b]{2}{*}{$\begin{array}{l}\text { Water } \\
\text { district }\end{array}$} & \multicolumn{2}{|c|}{$\begin{array}{c}\text { Water demand } \\
\left(\mathrm{Hm}^{3} / \text { year }\right)\end{array}$} & \multicolumn{2}{|c|}{$\begin{array}{c}\text { Financial cost } \\
(\text { /year })\end{array}$} & \multirow{2}{*}{$\begin{array}{c}\begin{array}{c}\text { Resource } \\
\text { cost ( /year) }\end{array} \\
\text { Irrigation }\end{array}$} & \multicolumn{2}{|c|}{ Environmental cost ( /year) } & \multicolumn{2}{|c|}{$\begin{array}{l}\text { Total costs } \\
\text { ( /year) }\end{array}$} \\
\hline & Irrigation & All uses & Irrigation & All uses & & Irrigation & All uses & Irrigation & All uses \\
\hline \begin{tabular}{|l|} 
1. West \\
Peloponnesos
\end{tabular} & 201.00 & 227.00 & 4689283 & 111514505 & 0 & 0 & 0 & 4689283 & 111514505 \\
\hline \begin{tabular}{|l|} 
2. North \\
Peloponnesos
\end{tabular} & 395.30 & 435.00 & 3028191 & 186157143 & 0 & 0 & 0 & 3028191 & 186157143 \\
\hline $\begin{array}{l}\text { 3. East } \\
\text { Peloponnesos }\end{array}$ & 324.90 & 347.03 & 12656841 & 165264301 & 3510184 & 0 & 0 & 16167025 & 168774485 \\
\hline $\begin{array}{l}\text { 4. West } \\
\text { Sterea Ellada } \\
\end{array}$ & 366.50 & 389.25 & 18603213 & 125050435 & 0 & 0 & 0 & 18603213 & 125050435 \\
\hline 5. Epirus & 127.40 & 162.30 & 9736162 & 208125860 & 0 & 0 & 0 & 9736162 & 208125860 \\
\hline 6. Attica & 99.00 & 500.50 & 906238 & 335641238 & 0 & 0 & 0 & 906238 & 335641238 \\
\hline $\begin{array}{l}\text { 7. East Sterea } \\
\text { Ellada }\end{array}$ & 773.70 & 827.90 & 3767101 & 186896053 & 20515680 & 3919685 & 7037231 & 28202466 & 214448964 \\
\hline 8. Thessaly & 155000 & 161905 & 15090667 & 488173793 & 89356467 & 7129974 & 9137486 & 111577108 & 586667746 \\
\hline $\begin{array}{l}\text { 9. West } \\
\text { Macedonia }\end{array}$ & 609.40 & 683.10 & 12874290 & 302828464 & 0 & 10785902 & 14535598 & 23660192 & 317364062 \\
\hline $\begin{array}{l}\text { 10. Central } \\
\text { Macedonia }\end{array}$ & 527.60 & 707.40 & 8123200 & 384238374 & 0 & 15281830 & 16586149 & 23405030 & 400824523 \\
\hline $\begin{array}{l}\text { 11. East } \\
\text { Macedonia }\end{array}$ & 627.00 & 659.32 & 9494351 & 177362557 & 0 & 3476094 & 5025462 & 12970445 & 182388019 \\
\hline 12. Thrace & 825.20 & 864.10 & 9601762 & 116426984 & 0 & 6908179 & 9842713 & 16509941 & 126269697 \\
\hline 13. Crete & 320.00 & 366.43 & 8690616 & 252862552 & 0 & 0 & 0 & 8690616 & 252862552 \\
\hline $\begin{array}{l}\text { 14. Aegean } \\
\text { Islands }\end{array}$ & 80.20 & 118.63 & 1688152 & 367946056 & 26784000 & 0 & 0 & 28472152 & 394730056 \\
\hline TOTAL & 6827.20 & 7907.02 & 118950067 & 3408488315 & 140166331 & 47501664 & 62164639 & 306618062 & 3610819285 \\
\hline
\end{tabular}

Resource costs have not been attributed to domestic and industrial uses, only to agricultural ones.

An empty cell denotes that the relevant cost has not been attributed in this use by the Greek government.

Source: MEPPPW (2008). Greece: Final Report for article 5 of the Water Framework Directive. Central Water Agency, Ministry of Environment, Physical Planning and Public Works, Hellenic Republic, Athens. 
Table 7. Full cost recovery for water services in Greece

\begin{tabular}{|c|c|c|c|c|c|c|}
\hline \multirow[b]{2}{*}{$\begin{array}{l}\text { Water } \\
\text { district }\end{array}$} & \multicolumn{2}{|c|}{$\begin{array}{l}\text { Revenue collected from water } \\
\text { tariffs ( /year) }\end{array}$} & \multicolumn{2}{|c|}{$\begin{array}{l}\text { Average water tariff } \\
\qquad\left(/ \mathbf{m}^{\mathbf{3}}\right)\end{array}$} & \multicolumn{2}{|c|}{$\begin{array}{l}\text { Total cost recovery } \\
(\%)\end{array}$} \\
\hline & Irrigation & All uses & Irrigation & All uses & Irrigation & All uses \\
\hline $\begin{array}{l}\text { 1.West } \\
\text { Peloponnesos }\end{array}$ & 3647690 & 70105941 & 0.0181 & 0.3088 & $77.79 \%$ & $62.87 \%$ \\
\hline $\begin{array}{l}\text { 2.North } \\
\text { Peloponnesos }\end{array}$ & 5519490 & 123507697 & 0.014 & 0.2839 & $182.27 \%$ & $66.35 \%$ \\
\hline $\begin{array}{l}\text { 3. East } \\
\text { Peloponnesos }\end{array}$ & 5740844 & 75121958 & 0.0177 & 0.2165 & $35.51 \%$ & $44.51 \%$ \\
\hline $\begin{array}{l}\text { 4.West } \\
\text { Sterea Ellada }\end{array}$ & 7197206 & 72434138 & 0.0196 & 0.1861 & $38.69 \%$ & $57.92 \%$ \\
\hline 5. Epirus & 2818647 & 143671846 & 0.0221 & 0.8852 & $28.95 \%$ & $69.03 \%$ \\
\hline 6. Attica & 1691811 & 363686811 & 0.0171 & 0.7266 & $186.69 \%$ & $108.36 \%$ \\
\hline $\begin{array}{l}\text { 7. East Sterea } \\
\text { Ellada }\end{array}$ & 12499562 & 152371950 & 0.0162 & 0.184 & $44.32 \%$ & $71.05 \%$ \\
\hline 8.Thessaly & 40222828 & 200067757 & 0.026 & 0.1236 & $36.05 \%$ & $34.10 \%$ \\
\hline $\begin{array}{l}\text { 9. West } \\
\text { Macedonia }\end{array}$ & 20866602 & 178150204 & 0.0342 & 0.2608 & $88.19 \%$ & $56.13 \%$ \\
\hline $\begin{array}{l}\text { 10. Central } \\
\text { Macedonia }\end{array}$ & 5780887 & 336967706 & 0.011 & 0.4763 & $24.70 \%$ & $84.07 \%$ \\
\hline $\begin{array}{l}\text { 11. East } \\
\text { Macedonia }\end{array}$ & 9252186 & 143750126 & 0.0148 & 0.218 & $71.33 \%$ & $78.82 \%$ \\
\hline 12.Thrace & 17450912 & 130659923 & 0.0211 & 0.1512 & $105.70 \%$ & $103.48 \%$ \\
\hline 13.Crete & 32000000 & 153281413 & 0.1 & 0.4183 & $368.21 \%$ & $60.62 \%$ \\
\hline $\begin{array}{l}\text { 14. Aegean } \\
\text { Islands }\end{array}$ & 919609 & 158177762 & 0.0115 & 13.334 & $3.23 \%$ & $40.07 \%$ \\
\hline TOTAL & 165608274 & 2301955232 & 0.0243 & 0.2911 & $54.01 \%$ & $63.75 \%$ \\
\hline
\end{tabular}

Source: MEPPPW (2008). Greece: Final Report for article 5 of the Water Framework Directive. Central Water Agency, Ministry of Environment, Physical Planning and Public Works, Hellenic Republic, Athens.

\section{Italy}

Irrigated agriculture in Italy accounts for $21 \%$ of agricultural land, $30 \%$ of farms and about $50 \%$ of total agricultural production. Around $60 \%$ of Italian agricultural exports are produced by irrigated agriculture (Leone 1997; Bazzani et al. 2003). Italy has unequally distributed water resources, more abundant, although increasingly pressured, in the Po Valley but scarce and unreliable in the South. Groundwater accounts on average for $30 \%$ of water sources in agriculture but it is the main source for agriculture in some areas of Toscany and Puglia, while surface water resources are predominant in the northern regions with the exception of Liguria (Farrace, 2007). Irrigated land is mostly located in the northern Po Valley (about 1.72 million hectares) and in the southern regions (about 800,000 hectares). Farming in Italy represents about $61 \%$ of consumptive use of water, with irrigation estimated at $45 \%$ of withdrawals. Water demand for agriculture has been decreasing since 1970 , although future water demand for irrigation is forecasted to stabilize around the present level of consumption (Massarutto 2001; Margat 2002). Regarding irrigation technologies, 37\% of the irrigated area in Italy is sprinkler irrigated, while $38 \%$ is irrigated by flooding or watering techniques and $20 \%$ is drip irrigated (Eurostat, 2005). 
The Land Reclamation Act (1933) converted all water bodies to the public domain, and set forth the principles which have guided the management of water resources in Italy ever since. The poorly maintained water distribution system in Italy relies mainly on "Reclamation and Irrigation Consortia" (RICs) (Consorzi di Bonifica e Irrigazione), that are managed by associations of landowners, entities regulated by public law that control land reclamation and water distribution in a certain area. RICs distribute about 50\% of the water used for irrigation (ANBI 1992 and 1998; AA.VV. 2001). Consortia have generally self-financing capacity to foster rural development and to build irrigation projects. However, in some regions Consortia are partly financed by regional administrations that in some cases even get to pay employees' wages. The government provides funds to cover all project capital costs, including investment costs, while the Consortia is responsible for managing and maintaining these systems, and collecting charges from farmers.

Average water cost at the farm level is about 36 /ha (Gallerani and Viaggi, 2003), but actual tariffs range from 0.60 /ha in Valle d'Aosta to 787 /ha in Latium (INEA, 2008). The tariff system is usually based on the running costs of servicing an area. Only in a small part of the total irrigated area is water measured and volumetrically priced. For instance, in the Romagna Occidentale Irrigation Consortium, $87 \%$ of the total area, served by open canals or non metered pipe systems, pay per hectare charges (42.6 and 132.2 /ha respectively), while the remaining $17 \%$, equipped with metered pressurized distribution systems, pay 20.66 /ha, plus a volumetric component (Gallerani and Viaggi 2003). The region with the highest presence of open canals for emergency irrigation is Veneto.

Italian farmers pay much less than other users. While domestic water is paid on a range of 0.13 to $2.42 / \mathrm{m}^{3}$ (INEA, 2008), agricultural users in most cases pay a small abstraction charge that is due in exchange for the license, and tariffs that cover only part of O\&M costs and nothing of investment or depreciation costs (Chohin-Kuper et al. 2003). Data on the price for irrigation water in Italy depends on the source: Farrace (2007) report values between 160 and 500 /ha, while Massarutto (2003) reports flat rate values on the ranges 50-150 /ha in the North and 30-100 /ha in the South and volumetric rates on the range 0.04 to $0.07 / \mathrm{m}^{3}$ in the South.

Massarutto (2003) reports a range of 70 to $100 \%$ O\&M recovery rates in Northern Italy and 20 to $100 \%$ in the South. Full cost recovery rates would be in the range 50 to $80 \%$ in the North and 20 to $30 \%$ in the South (Massarutto, 2001). However, it must be taken into account that storage facilities are shared with other users (hydropower generation in the North and public water supply companies in the South.

As an example, in Sardinia, rates vary within each Consortia based on the type of water conveyance system, pressure, crops and irrigation technology, ranging from a flat rate of 50 /ha for drip irrigators in Nurra Consortia to 384 /ha for rice growers in Campidano di Oristano Consortia (Aiello et al. 1997). Xiloyannis and Dichio (2001) find large water consumption differences for the same crops between a district in Bassilicata (a flat per ha rate) and another in Puglia that uses a blockrate system (a flat rate of $10 /$ ha plus a variable rate of $0.09 / \mathrm{m}^{3}\left(0-1300 \mathrm{~m}^{3} / \mathrm{ha}\right), 0.056 / \mathrm{m}^{3}(1300$ $2000 \mathrm{~m}^{3} / \mathrm{ha}$ ), $0.091 / \mathrm{m}^{3}\left(2000-3000 \mathrm{~m}^{3} / \mathrm{ha}\right.$ ) and $0.126 / \mathrm{m}^{3}$ (for any unit exceeding $4,000 \mathrm{~m}^{3} / \mathrm{ha}$ ). Table 8 reports tariffs and full supply cost recovery rates for three Italian irrigation districts.

Unfortunately, information concerning WFD art.5's for Italy on water prices and full cost recovery rates was not found in the only available report ${ }^{3}$.

3. Rapporto di ricerca attuazione Della direttiva 2000/60/CE in Italia. Edizione 2007. Presidenza del Consiglio dei Ministri. Formez. 
Table 8. Examples of tariffs and full supply cost recovery rates in three Italian irrigation districts

\begin{tabular}{|l|c|c|}
\hline Type of district & $\begin{array}{c}\text { Tariff } \\
\left(/ \mathbf{m}^{\mathbf{3}}\right)\end{array}$ & $\begin{array}{c}\text { Financial (i.e. full supply) } \\
\text { cost-recovery rates }\end{array}$ \\
\hline Continental (maize); North Italy; 27,800 ha & 0.015 & Nearly achieved (70-80\%) \\
\hline Mediterranean (horticulture); Central Italy; 8,200 ha & $0.04-0.1$ & $\begin{array}{c}\text { Substantially achieved } \\
(50-60 \%)\end{array}$ \\
\hline $\begin{array}{l}\text { Mediterranean (fruit, vegetable and durum wheat); } \\
\text { South Italy; 180,000 ha }\end{array}$ & $0.08-0.1$ & $\begin{array}{c}\text { Achieved for operational cost } \\
\text { only (50\%) }\end{array}$ \\
\hline
\end{tabular}

Source: Massarutto (2003). Tariffs are the volumetric equivalent of per hectare rates.

\section{Portugal}

Portugal is relatively well endowed with water resources, although huge differences exist between the North and the South. Irrigated land constitutes about $61 \%$ of the nation's total water supply and $25 \%$ of the agricultural area.

The Portuguese Water Law combines public and private ownership of water resources. Unlike most countries, the State's role in promoting irrigation projects in Portugal has traditionally been quite limited. Purely public irrigation projects make up only $19-25 \%$ of the 616,970 hectares of land that are equipped for irrigation (Table 1), most of which are located in the southern regions, which makes the role of public water pricing policies less important for national-level water management strategy. Traditionally, water abstractions have been allowed free of charge, provided that users do not generate significant levels of pollution. However, major institutional and legal progress has been recently made in terms of implementing water charges for public projects.

Agricultural water tariffs are levied by water users' associations in accordance with very complex mechanisms and formulae. The complexity arises because WUAs sometimes supply municipal water as well, property size affects the water charges, and charges are combined with drainage fees in projects that require drainage (Castro 1997). Project beneficiaries are required to pay a yearly set charge called TEC (Taxa de Exploração e Conservação) which includes a selection of no more than three of the following components: (1) a fixed charge per reclaimed or ameliorated hectare of land; (2) a fixed charge per irrigated hectare; (3) a volumetric charge per cubic meter, if metering is possible; (4) a drainage fee, when drainage of excessive water is required; and (5) a crop-based fee applicable for specific crops and projects (Bragança 1998). Table 9 reports the evolution between 1998 and 2007 of these irrigation water charge components according to data prodiced by Bragança (1998) and DGADR (2005 and 2007), that is the public entity responsible for the managing bodies (WUA) of Collective Irrigation Projects of State Initiative (AHCIE).

Table 9. Irrigation water charges in public irrigation projects (1998-2007)

\begin{tabular}{|l|c|c|c|}
\hline \multicolumn{1}{|c|}{ Pricing models } & $\begin{array}{c}\text { Bragança, 1998 } \\
\text { (OECD study) } \\
\text { (USD) }\end{array}$ & $\begin{array}{c}\text { DGADR, 2005 } \\
\text { (EUR) }\end{array}$ & $\begin{array}{c}\text { DGADR, 2007 } \\
\text { (EUR) }\end{array}$ \\
\hline Fixed rate per ha improved & 18 to 270 & 16.21 to 215.48 & 16.21 to 221 \\
\hline Fixed rate per ha irrigated & 31 to 146 & 16.21 to 45.45 & 18 to 115 \\
\hline Volumetric rate per m ${ }^{3}$ used & 0.01 to 0.028 & 0.0107 to 0.065 & 0.011 to 0.092 \\
\hline Drainage rate (per ha) & 19 to 67 & 19.3 to 197 & 38.9 to 210 \\
\hline Rate per ha of irrigated crop & 16.9 to 87.3 & 10 to 203.3 & 13 to 210.9 \\
\hline
\end{tabular}


Although the capital cost charge element has never achieved its intended objective of full supply cost recovery, the Portuguese system has the peculiarity to compute its payable fees using different interest rates, with the rates varying with soil quality and the crops grown. For instance, Brangança (1998) reports significant water price differences paid by farmers in Sorraia: $0.0076 / \mathrm{m}^{3}$ for rice $\left(17,200 \mathrm{~m}^{3} / \mathrm{ha}\right)$ and or corn $\left(7,200 \mathrm{~m}^{3} / \mathrm{ha}\right)$; and $0.0124 / \mathrm{m}^{3}$ for tomato $\left(5,400 \mathrm{~m}^{3} / \mathrm{ha}\right)$. It is clear that the "ability-to-pay" principle, combined with other agricultural policy objectives, underlies these price differentials. Nonetheless, charges in Sorraia were gradually raised in the period 1991-97, up to levels that exceed O\&M costs.

Individual irrigators pay a $100 \%$ of all O\&M and capital costs, although investments in irrigation equipment and adaptation to irrigation has been increasingly financed by both the EU and the Portuguese Government with variable non recoverable contributions since Portugal entered the EU in 1986. Farmers in collective schemes pay on average $90 \%$ of operational and maintenance costs and none of capital costs (Massarutto, 2003)). Average flat rate in Portugal would be 120 /ha while average volumetric tariff would be $0.02 / \mathrm{m}^{3}$.

Table 10 comprises the official data for the cost recovery rates for the ten water regions Portugal is divided in, that has been elaborated from the information in the Portuguese Final Report for Article 5 of the Water Framework Directive (MAOTDR, 2005) and the reports for both the Açores (SRA, 2006) and Madeira Islands (SRAM, 2006). The full supply cost recovery analysis elaborated by the Portuguese Ministry of Environment includes only the financial cost of water services and a small part of resource and environmental costs (only that part that has been effectively paid). The noninternalized part of environmental and resource costs have not been calculated. However, the Portuguese Ministry of Environment considers that the investment in sewage water treatment infrastructures to minimise the impact on water bodies accounts for part of the environmental costs. The full supply cost recovery analysis has been elaborated with data for 2002 considering both urban water supply and drainage and wastewater treatment systems and agricultural water supply systems. Details on how the full supply cost recovery analysis has been elaborated can be found in MAOTDR (2005). However, we now comment how the cost recovery analysis has been elaborated for agricultural uses.

For agricultural users, financial costs have been calculated only for public irrigation districts (Aproveitamentos Hidroagrícolas Colectivos Estatais, AHCE) that were operating at the end of 2003. These are irrigation areas built by the government and managed by water users' associations and/or other beneficiaries. Once environmental costs were not considered, private agricultural users are assumed to totally recover all their financial (full supply) costs. Costs (and revenues) considered for public irrigated areas are those associated to the irrigation and drainage services, including the costs of irrigation/drainage infrastructures and the costs of dams associated with the AHCEs that are used for irrigation. Full supply cost recovery level has been calculated considering both total financial costs and only the operational costs of irrigation infrastructures.

Data for agricultural users has been obtained from the AHCEs and existing studies on irrigated areas. Financial (full supply) costs considered include both investment and operation and maintenance $(\mathrm{O} \& \mathrm{M})$ costs. Investment costs were calculated using data for the whole period each AHCE was operating up until 2002. This data was discounted to 2002 prices, then summed up, and lastly annualized considering a useful lifetime of 75 years for reservoirs and 50 years for other infrastructures. For dams that serve multiple uses, the percentage of their corresponding investment costs attributable to irrigation was calculated considering the average volumes served for irrigation in 1998-2002 weighted by a 95\% supply reliability for urban users and a $65 \%$ supply reliability for other uses (including irrigation). Operation and maintenance costs for dams have been estimated as a $1 \%$ of the dam's investment costs calculated for 2002. For other infrastructures, only operation costs have been estimated. The reason is that the Portuguese Government gives is that it is difficult to separate between the costs of traditional maintenance and the cost of large repairs and improvements that can be incorporated in the value of infrastructures. In fact, investment costs considered already include complementary works and improvements in infrastructures. Operation costs have been estimated considering an annual per hectare cost of 99.76 and the irrigated area in 2002. Revenues are those collected by the AHCEs in the reference year 2002. 
As shown in Table 10, tariffs paid by urban users in continental Portugal cover on average $82 \%$ of total supply, drainage and wastewater treatment costs. With a couple of notable exceptions for urban users (Regions 5 and 6), water companies do not even cover their financial (full supply) costs. Regarding agricultural uses, the average cost recovery rate is $23 \%$ for all financial costs and $114 \%$ if only operational costs are considered. In some regions, tariffs paid by agricultural users do not even cover operational costs. The Portuguese report does not calculate the cost recovery figure for all uses, nor includes data for its calculation, as it does not reports data on water consumption, costs and revenues.

Table 10. Full supply cost recovery for water services in Portugal

\begin{tabular}{|l|c|c|c|}
\hline & $\begin{array}{c}\text { Total cost recovery in urban, } \\
\text { drainage and wastewater } \\
\text { treatment systems } \\
(\%)\end{array}$ & $\begin{array}{c}\text { Financial cost recovery in } \\
\text { agriculture (\%) }\end{array}$ \\
\cline { 3 - 4 } & 78 & $\begin{array}{c}\text { Operational } \\
\text { costs (\%) }\end{array}$ & $\begin{array}{c}\text { Total costs } \\
(\%)\end{array}$ \\
\hline RH 1 (Minho e Lima) & 76 & n.a. & n.a. \\
\hline RH 2 (Cavado, Ave e Leça) & 61 & n.a. & n.a. \\
\hline RH 3 (Douro) & 65 & 103 & 9 \\
\hline RH 4 (Vouga, Mondego e Lis) & 96 & 80 & 10 \\
\hline RH 5 (Tejo e ribeiras do Oeste) & 81 & 124 & 28 \\
\hline RH 6 (Sado e Mira) & 64 & 104 & 35 \\
\hline RH 7 (Guadiana) & 72 & 93 & 13 \\
\hline RH 8 (Ribeiras do Algarve) & n.a. & n.a. & n.a. \\
\hline RH 9 (Arquipélago dos Açores) & n.a. & n.a. & n.a. \\
\hline RH 10 (Arquipélago da Madeira) & $\mathbf{8 2}$ & $\mathbf{1 1 4}$ & $\mathbf{2 3}$ \\
\hline Continental Portugal & & & 37 \\
\hline
\end{tabular}

Urban uses comprise domestic consumption plus other uses served from urban supply networks. Only those resource and environmental costs that have been effectively internalized have been considered. External environmental and resource costs have not been calculated nor included in the analysis. Users that abstract water directly are considered to have a full financial supply cost recovery and are not considered in the analysis.

Sources: MAOTDR (2005), SRA (2006) and SRAM (2006).

\section{Spain}

Spain's water charges have been thoroughly documented in the literature and official documentation. About $70 \%$ of all Spanish irrigated acreage is serviced by irrigators' communities or districts, of which there are more than 6,500 registered (6,000 being smaller than 1,000 ha.)

In addition to administering the resources and infrastructures they share water among irrigators, and have a major role in water management both at the River Basin Authority (RBA) and district levels. They are active members in the governing and planning boards, and have permanent seats in the Basin Assembly of Users. Farmers pay the 'regulation levy' and the 'water use tariff' to the RBA through the irrigation district (ID), plus an additional tariff to cover the costs of the irrigation district itself (called "derrama"). IDs that abstract their water directly and that use publicly developed infrastructures only pay the regulation levy plus their own pumping, transport and application costs.

Average tariffs paid for irrigation water in areas where water is supplied by RBAs is $0.02 / \mathrm{m}^{3}$, except for the agricultural users served from the Tagus-Segura inter-basin transfer who pay about $0.09 / \mathrm{m}^{3}$ (with a final cost for farmers of $0.13 / \mathrm{m}^{3}$ ), whereas areas that use groundwater pay an average of 0.04 to $0.07 / \mathrm{m} 3$, based on extraction and other O\&M costs. Groundwater users pay their financial, energy, operation and maintenance costs directly. A study at the Júcar Basin (MMA, 2004) 
indicates that about $90 \%$ of all the expenses related to surface and groundwater are not controlled by the RBA, but by the private economy. In the Júcar Basin, most customers are groundwater users.

These figures are well below the public costs incurred to supply the water. In Andalusia (Guadalquivir, Guadiana and Sur basins), where irrigation water comes predominantly from surface resources, average water tariffs for surface water are about $0.01 \mathrm{l} 3$, with a final cost for farmers, including other water-related variable costs, of 0.03 to $0.04 / \mathrm{m} 3$, whereas it costs the Administration about $0.12 / \mathrm{m} 3$ on average to supply the water (Corominas 2001). The total cost for farmers using groundwater ranges from 0.13 to $0.5 / \mathrm{m} 3$.

On the other hand, still in Spain, we have the case of the Júcar and Segura basins. In the eastern Valencia region, where the use of groundwater is very intense and predominates, the final cost of water for farmers ranges between 0.04 and $0.22 / \mathrm{m}^{3}$ for surface water and groundwater, respectively, with an average of $0.115 / \mathrm{m}^{3}$ (Carles et al., 2001; García et al., 2004).

Similarly, in the South-Eastern Segura basin, one of the areas with higher water scarcity in the country, water cost for farmers are on the range $0.03-0.20 / \mathrm{m}^{3}$ with an average of $0.11 / \mathrm{m}^{3}$ (CHS, 2007). In this basin a vast majority of farmers pay volumetric tariffs and have to rely on several sources with different prices to complete their allotment. Average cost born by farmers for surface water is $0.03 / \mathrm{m}^{3}$ for the basin's own resources, $0.13 / \mathrm{m}^{3}$ for surface water transferred from the Tagus basin, $0.03 / \mathrm{m}^{3}$ for depurated sewage water and $0.34 / \mathrm{m}^{3}$ for desalinised water (CHS, 2007). The cost of groundwater resources for farmers are on the range $0.102-0.33 \mathrm{Im}^{3}$, with an average of $0.115 / \mathrm{m}^{3}$.

Examples of farmers' charges for different districts and RBAs all around the country are reported in Table 11. Generally, these figures are wholly applicable to 2007.

Most irrigated areas in Spain have opted for one of the following pricing schemes (MAPA 2001):

- A fixed per-hectare tariff, calculated as the total costs attributable to farmers divided by total irrigated area. It is the most common option in the traditional districts served from surface resources. In all, fixed rates are applied across $82 \%$ of the surface water irrigated acreage in Spain.

- A volumetric tariff, more frequent in districts served from groundwater and/or incurring energy costs, is applied across $13 \%$ of the irrigated hectares. Volumetric tariffs are applied (1) as an amount per m3 served; (2) with rates for each time a hectare of land is irrigated, and (3) with rates per hour of irrigating time.

- A binomial tariff combining a volumetric rate to cover variable costs with a fixed per hectare rate for investment and management costs, applied across the 5\% of the irrigated acreage. Binomial tariffs are more predominant in private and modern publicly developed districts, where metering devices exist and energy costs are substantial.

García Mollá (2002), cited by MMA (2007) distinguished in the Jucar basin, the following types of water tariffs:

- $\quad$ Two-part: per ha + number of water applications

- Two-part: per ha + duration of turn

- Per ha

- Two-part: per ha + (duration of turn and number of water applications).

- Two-part: par ha + volumetric

- Duration of turn

- Duration of turns and number of applications. 
Table 11. Tariff schemes for several Spanish irrigation districts and RBAs

\begin{tabular}{|c|c|c|c|c|c|c|c|c|c|c|c|}
\hline \multirow{2}{*}{ District } & \multirow{2}{*}{ Basin } & \multirow{2}{*}{$\begin{array}{c}\text { Type of } \\
\text { district } \\
\text { (surface } \\
\text { in ha) }\end{array}$} & \multirow{2}{*}{$\begin{array}{l}\text { Irrigation } \\
\text { system } \\
\text { (F:Furrow } \\
\text { S: Sprinkler } \\
\text { D: Drip) }\end{array}$} & \multirow{2}{*}{$\begin{array}{c}\text { Average } \\
\text { allotment } \\
\left(\mathrm{m}^{3} / \mathrm{ha}\right)\end{array}$} & \multirow{2}{*}{$\begin{array}{l}\text { Water } \\
\text { Supply }\end{array}$} & \multirow{2}{*}{$\begin{array}{l}\text { Type of } \\
\text { tariff }\end{array}$} & \multicolumn{3}{|c|}{ Per hectare tariff ( /ha) } & \multirow{2}{*}{$\begin{array}{c}\text { Volumetric } \\
\text { term } \\
\left(/ \mathrm{m}^{3}\right)\end{array}$} & \multirow{2}{*}{ Source+ } \\
\hline & & & & & & & $\begin{array}{c}\text { Regulation } \\
\text { levy + water } \\
\text { use tariff (a) }\end{array}$ & $\begin{array}{c}\text { District } \\
\text { tariff } \\
\text { (b) } \\
\end{array}$ & $\begin{array}{l}\text { Total } \\
(\mathrm{a}+\mathrm{b})\end{array}$ & & \\
\hline Guadalmellato & Guadalquivir & $\begin{array}{l}\text { Old private } \\
\text { district } \\
(6,129 \text { ha })\end{array}$ & F/S/D & 6000 & Surface & $\begin{array}{l}\text { Fixed per } \\
\text { hectare }\end{array}$ & & & 150 & - & 1 \\
\hline $\begin{array}{l}\text { B-XII (Bajo } \\
\text { Guadalquivir) }\end{array}$ & Guadalquivir & $\begin{array}{l}\text { Old public } \\
\text { district } \\
(11,900 \text { ha })\end{array}$ & F/D & 6000 & Surface & $\begin{array}{l}\text { Fixed per } \\
\text { hectare }\end{array}$ & & & $165^{*}$ & - & 2 \\
\hline Genil-Cabra & Guadalquivir & $\begin{array}{l}\text { Modern } \\
\text { public } \\
\text { district } \\
(15,000 \mathrm{ha})\end{array}$ & S/D & 4000 & $\begin{array}{l}\text { Surface and } \\
\text { groundwater }\end{array}$ & Binomial & & & 85 & 0.025 & 2 \\
\hline Fuente-Palmera & Guadalquivir & $\begin{array}{l}\text { Modern } \\
\text { public } \\
\text { district } \\
(5,260 \mathrm{ha})\end{array}$ & S/D & 4200 & $\begin{array}{l}\text { Surface } \\
\text { (pumped) }\end{array}$ & Binomial & 52 & 39 & 91 & 0.06 & 2 \\
\hline El Viar & Guadalquivir & $\begin{array}{l}\text { Old private } \\
\text { district } \\
(12,000 \mathrm{ha})\end{array}$ & F/D & 7000 & Surface & $\begin{array}{l}\text { Fixed per } \\
\text { hectare }\end{array}$ & & & 103 & - & 2 \\
\hline $\begin{array}{l}\text { Riegos de } \\
\text { Levante (MI) }\end{array}$ & Segura & (26,399 ha) & $\mathrm{F} / \mathrm{D}$ & $\begin{array}{c}7200 \text { to } \\
9600\end{array}$ & Surface & Binomial & - & 45 & 45 & $0.105^{* *}$ & $2 \& 3$ \\
\hline $\begin{array}{l}\text { Riegos de } \\
\text { Levante (MD) }\end{array}$ & Segura & $\begin{array}{l}\text { Traditional } \\
\text { public } \\
\text { district } \\
(4,183 \mathrm{ha})\end{array}$ & F/D & 5100 & Surface & Binomial & & & 25 & $0.184^{* *}$ & 3 \\
\hline $\begin{array}{l}\text { Com. de } \\
\text { usuarios de } \\
\text { Novelda }\end{array}$ & Segura & $\begin{array}{l}\text { Private, } \\
\text { specialty } \\
\text { crops } \\
(2,056 \mathrm{ha})\end{array}$ & $\mathrm{F}$ & 6000 & Groundwater & Binomial & - & 85 & & $0.151^{* *}$ & $2 \& 3$ \\
\hline $\begin{array}{l}\text { Acequia Real } \\
\text { del Júcar }\end{array}$ & Júcar & $\begin{array}{l}\text { Historical } \\
\text { district } \\
(21,736 \text { ha })\end{array}$ & F/D & 12600 & Surface & $\begin{array}{l}\text { Fixed per } \\
\text { hectare }\end{array}$ & & & $211^{* *}$ & - & $2 \& 3$ \\
\hline $\begin{array}{l}\text { Canal Cota 220, } \\
\text { Onda }\end{array}$ & Júcar & $\begin{array}{l}\text { Modern } \\
\text { district } \\
(2,179 \text { ha })\end{array}$ & F/D & 7200 & $\begin{array}{l}\text { Surface and } \\
\text { groundwater }\end{array}$ & Binomial & 3 & - & 3 & $0.1^{* *}$ & 2 \\
\hline
\end{tabular}




\begin{tabular}{|c|c|c|c|c|c|c|c|c|c|c|c|}
\hline \multirow{2}{*}{ District } & \multirow{2}{*}{ Basin } & \multirow{2}{*}{$\begin{array}{c}\text { Type of } \\
\text { district } \\
\text { (surface } \\
\text { in ha) }\end{array}$} & \multirow{2}{*}{$\begin{array}{l}\text { Irrigation } \\
\text { system } \\
\text { (F:Furrow } \\
\text { S: Sprinkler } \\
\text { D: Drip) }\end{array}$} & \multirow{2}{*}{$\begin{array}{l}\text { Average } \\
\text { allotment } \\
\left(\mathrm{m}^{3} / \mathrm{ha}\right)\end{array}$} & \multirow{2}{*}{$\begin{array}{l}\text { Water } \\
\text { Supply }\end{array}$} & \multirow{2}{*}{$\begin{array}{c}\text { Type of } \\
\text { tariff }\end{array}$} & \multicolumn{3}{|c|}{ Per hectare tariff $(\mathrm{ha})$} & \multirow{2}{*}{$\begin{array}{c}\text { Volumetric } \\
\text { term } \\
\left(/ \mathrm{m}^{3}\right)\end{array}$} & \multirow{2}{*}{ Source-t } \\
\hline & & & & & & & $\begin{array}{c}\text { Regulation } \\
\text { levy + water } \\
\text { use tariff (a) }\end{array}$ & $\begin{array}{c}\text { District } \\
\text { tariff } \\
\text { (b) }\end{array}$ & $\begin{array}{l}\text { Total } \\
(\mathrm{a}+\mathrm{b})\end{array}$ & & \\
\hline Vall D’Uxó & Júcar & $\begin{array}{l}\text { Private } \\
\text { district } \\
(2,882 \text { ha })\end{array}$ & F/D & 7500 & Groundwater & Binomial & - & 210 & & $0.121^{* *}$ & $2 \& 3$ \\
\hline $\begin{array}{l}\text { Callosa d'En } \\
\text { Sarriá (part) }\end{array}$ & Júcar & \begin{tabular}{|l|} 
Traditional \\
district \\
$(2,083 \mathrm{ha})$ \\
\end{tabular} & $\mathrm{F}$ & 9000 & Surface & $\begin{array}{c}\text { Fixed per } \\
\text { hectare }\end{array}$ & - & $332-764$ & & - & 3 \\
\hline $\begin{array}{l}\text { Callosa d'En } \\
\text { Sarriá (rest) }\end{array}$ & Júcar & \begin{tabular}{|l|} 
Traditional \\
district \\
$(2,083$ ha $)$ \\
\end{tabular} & $\mathrm{D}$ & 9000 & Surface & Volumetric & - & - & - & 0.11 & 3 \\
\hline Canal Cota 100 & Júcar & $\begin{array}{l}\text { Modern } \\
\text { district } \\
(3,352 \text { ha })\end{array}$ & F/D & & $\begin{array}{l}\text { Surface and } \\
\text { groundwater }\end{array}$ & Binomial & 3 & - & 3 & $0.05^{* *}$ & 3 \\
\hline Babilafuente & Duero & $\begin{array}{l}\text { Old public } \\
\text { district } \\
(3,570 \mathrm{ha})\end{array}$ & $\mathrm{F} / \mathrm{S}$ & 13000 & & $\begin{array}{l}\text { Fixed per } \\
\text { hectare }\end{array}$ & 66 & 6 & 72 & - & 2 \\
\hline Villoria & Duero & \begin{tabular}{|l|} 
Publicly \\
developed \\
district \\
$(5,220$ ha $)$
\end{tabular} & $\mathrm{S}$ & 4000 & & $\begin{array}{l}\text { Fixed per } \\
\text { hectare }\end{array}$ & $138^{*}$ & 12 & 150 & - & 2 \\
\hline Villalar & Duero & \begin{tabular}{|l} 
Modern \\
public \\
district (510 \\
ha) \\
\end{tabular} & $\mathrm{S}$ & Unlimited & Groundwater & Volumetric & - & - & - & 0.06 & 2 \\
\hline $\begin{array}{l}\text { Canal del } \\
\text { Páramo }\end{array}$ & Duero & \begin{tabular}{|l|} 
Old public \\
district \\
$(15,500$ ha $)$
\end{tabular} & $\mathrm{F} / \mathrm{S}$ & 7500 & & $\begin{array}{l}\text { Fixed per } \\
\text { hectare }\end{array}$ & 66 & 9 & 75 & - & 2 \\
\hline $\begin{array}{l}\text { Canal de la } \\
\text { Retención }\end{array}$ & Duero & \begin{tabular}{|l|} 
Publicly \\
developed \\
district \\
$(3,514$ ha $)$ \\
\end{tabular} & $\mathrm{F} / \mathrm{S}$ & 7000 & & $\begin{array}{c}\text { Fixed per } \\
\text { hectare }\end{array}$ & 33 & 12 & 45 & - & 2 \\
\hline Daimiel & Guadiana & $(19,000$ ha $)$ & S/D & $\begin{array}{l}\text { Depending } \\
\text { on size }\end{array}$ & Groundwater & Binomial & - & - & - & $\begin{array}{c}5 \text { /ha + } \\
9 \text { /well + } \\
\text { energy } \\
\text { cost }\end{array}$ & 2 \\
\hline
\end{tabular}




\begin{tabular}{|c|c|c|c|c|c|c|c|c|c|c|c|}
\hline \multirow{2}{*}{ District } & \multirow{2}{*}{ Basin } & \multirow{2}{*}{$\begin{array}{c}\text { Type of } \\
\text { district } \\
\text { (surface } \\
\text { in ha) }\end{array}$} & \multirow{2}{*}{$\begin{array}{l}\text { Irrigation } \\
\text { system } \\
\text { (F:Furrow } \\
\text { S: Sprinkler } \\
\text { D: Drip) }\end{array}$} & \multirow{2}{*}{$\begin{array}{l}\text { Average } \\
\text { allotment } \\
\left(\mathrm{m}^{3} / \mathrm{ha}\right)\end{array}$} & \multirow{2}{*}{$\begin{array}{l}\text { Water } \\
\text { Supply }\end{array}$} & \multirow{2}{*}{$\begin{array}{l}\text { Type of } \\
\text { tariff }\end{array}$} & \multicolumn{3}{|c|}{ Per hectare tariff ( /ha) } & \multirow{2}{*}{$\begin{array}{c}\text { Volumetric } \\
\text { term } \\
\left(/ \mathrm{m}^{3}\right)\end{array}$} & \multirow{2}{*}{ Source+ } \\
\hline & & & & & & & $\begin{array}{l}\text { Regulation } \\
\text { levy + water } \\
\text { use tariff (a) }\end{array}$ & $\begin{array}{l}\text { District } \\
\text { tariff } \\
\text { (b) }\end{array}$ & $\begin{array}{l}\text { Total } \\
(\mathrm{a}+\mathrm{b})\end{array}$ & & \\
\hline Bajo Carrión & Duero & \begin{tabular}{|l|} 
Modern \\
public \\
$(6,600)$
\end{tabular} & $\mathrm{F} / \mathrm{S}$ & 4500 & Surface & Per hectare & 26 & 12 & 38 & - & 4 \\
\hline $\begin{array}{l}\text { Loma de } \\
\text { Quinto }\end{array}$ & Ebro & $\begin{array}{l}\text { Modern } \\
\text { public } \\
\text { district } \\
(2,606)\end{array}$ & $S$ & 5850 & $\begin{array}{l}\begin{array}{l}\text { Surface } \\
\text { (pumped) }\end{array} \\
\end{array}$ & Volumetric & - & - & - & 0.034 & 5 \\
\hline $\begin{array}{l}\text { Monegros- } \\
\text { Cinca }\end{array}$ & Ebro & \begin{tabular}{|l} 
Public \\
$(100,000)$
\end{tabular} & & 10000 & Surface & Per hectare & & & 60 & - & 6 \\
\hline $\begin{array}{l}\text { Canal de } \\
\text { Aragón }\end{array}$ & Ebro & \begin{tabular}{|l} 
Public \\
modern \\
$(105,000)$
\end{tabular} & & 5700 & Surface & Volumetric & - & - & - & $0.05-0.07$ & 6 \\
\hline San José & Sur & $\begin{array}{l}\text { Private, } \\
\text { fruit } \\
\text { (189 ha) }\end{array}$ & $\mathrm{S} / \mathrm{D}$ & 5045 & Groundwater & Binomial & & & $\begin{array}{c}144 \\
(36 \\
\text { /share) }\end{array}$ & 0.14 & 7 \\
\hline
\end{tabular}

All volume-related tariffs (per irrigation turn, per volume or per duration of irrigation) have been converted to per-volume amounts.

( ) Includes the cost of labour of the district worker that manages the system.

${ }^{+}$References: 1: Calatrava (2002); 2, Sumpsi et al. (1998); 3, García (2002); 4 Gómez-Limón et al. (2002); 5: Dechmi et al. (2003); 6, Arrojo (2001); 7 Calatrava and Sayadi (2005). 
While Table 12's right column provides average full supply cost recovery rates for the principal basins in Spain, very few available studies permit a detailed application of the criterions for cost evaluations and the cost recovery rates. Pérez and Barreiro (2007) performed a detailed evaluation of cost recovery rates at the wholesale level of the Gállego basin (a tributary of the Ebro), applying the Spanish Water Law criterions. Among the most crucial assumptions of their exercise were: (a) capital replacement costs were not taken into account; (b) since canals were more than 25-year old, amortisation rates were set to zero; (c) a cost sharing rate to irrigation of 50\% among the remaining sectors (flood control, 12\%; hydropower, 32\%; urban and commercial, 5\%). They came up with a full financial supply cost recovery charge equivalent to $0.0077 / \mathrm{m} 3$, whereas the actual rate is in the Gállego basin $0.00403 / \mathrm{m} 3$, that is an actual cost recovery rate of $52 \%$.

Table 12. Payments for irrigation water services in Spain (only in the inter-regional basins)

\begin{tabular}{|c|c|c|c|c|c|c|c|c|}
\hline \multirow[b]{3}{*}{ Basin } & \multicolumn{2}{|c|}{ Groundwater } & \multicolumn{3}{|c|}{ Surface } & \multicolumn{2}{|c|}{ Total } & \multirow{3}{*}{$\begin{array}{c}\text { Financial } \\
\text { (full } \\
\text { supply) } \\
\text { cost } \\
\text { recovery } \\
\text { rates }\end{array}$} \\
\hline & \multirow[b]{2}{*}{ per ha } & \multirow[b]{2}{*}{ per $\mathbf{m}^{3}$} & \multicolumn{2}{|c|}{ Per ha } & \multirow[b]{2}{*}{ per $\mathbf{m}^{3}$} & \multirow[b]{2}{*}{ per ha } & \multirow[b]{2}{*}{ per $\mathbf{m}^{3}$} & \\
\hline & & & Distribution & $\begin{array}{c}\text { ID and } \\
\text { Basin } \\
\text { tariff }\end{array}$ & & & & \\
\hline Duero & 500 & 0.095 & 19.88 & 46 & 0.012 & 231 & 0.044 & $86.10 \%$ \\
\hline Ebro & 829 & 0.15 & 49 & 12 & 0.011 & 113 & 0.02 & $89 \%$ \\
\hline Guadalquivir & 744 & 0.15 & 101 & 70 & 0.035 & 400 & 0.081 & $97.70 \%$ \\
\hline Guadiana & 232 & 0.048 & 19 & 102 & 0.025 & 188 & 0.039 & $54.10 \%$ \\
\hline Júcar & 383 & 0.074 & 81 & 16 & 0.02 & 283 & 0.055 & $85 \%$ \\
\hline Segura & 789 & 0.163 & 34 & 151 & 0.038 & 463.8 & 0.096 & n.a. \\
\hline Tagus & 541 & 0.1 & 36 & 67 & 0.02 & 199.3 & 0.038 & n.a. \\
\hline Total & 500 & 0.09 & 50 & 56 & 0.021 & 263.5 & 0.051 & $87.10 \%$ \\
\hline
\end{tabular}

Source: MMA (2007).

Since 2001, 95\% of the budget devoted to irrigation in Spain is targeted to finance modernization projects, which have reached 1.3 Mha and a budget of 4 billion euros (Barbero, 2005). Beneficiary farmers must pay only $50 \%$ of the project's costs, for which they are granted preferential loans. But the process is becoming very costly, as projects have been re-focused to include environmental, structural, technological and land planning/tenancy components. The gains are private in the form of more efficient and productive districts, as well as public in the form of water conservation and reduced pollution. By no means would farmers' full supply cost-recovery rates suffice to finance such projects. Yet they are praised and uncontested.

\section{Mexico}

Irrigated agriculture in Mexico is extremely important both in terms of irrigated acreage (more than 5.5 million hectares) and total water use. Since the passing of the Water Law in 1992 and the creation of the National Water Commission, Mexico embarked in a massive policy reform to devolve water management of its large water districts to the recently created users associations (Tsur et al. 2004). This involved setting new institutions such as basin agencies, giving WUAs managing capacity to administer both capital assets and water resources, and transferring the financial responsibility of running districts and collecting charges to the WUAs. Tsur et al (2004) reports that between 1990 and 1996 government water subsidies and tariff deficit had gone down to 15\% and $13 \%$, respectively, from $35 \%$ and $26 \%$. The analysis of water irrigation pricing in Mexico cannot be dissociated from the evaluation of irrigation management transfer programmes (ITM). 
Figure 2. Mexico Irrigation Management Transfer Program (1990-2006)*

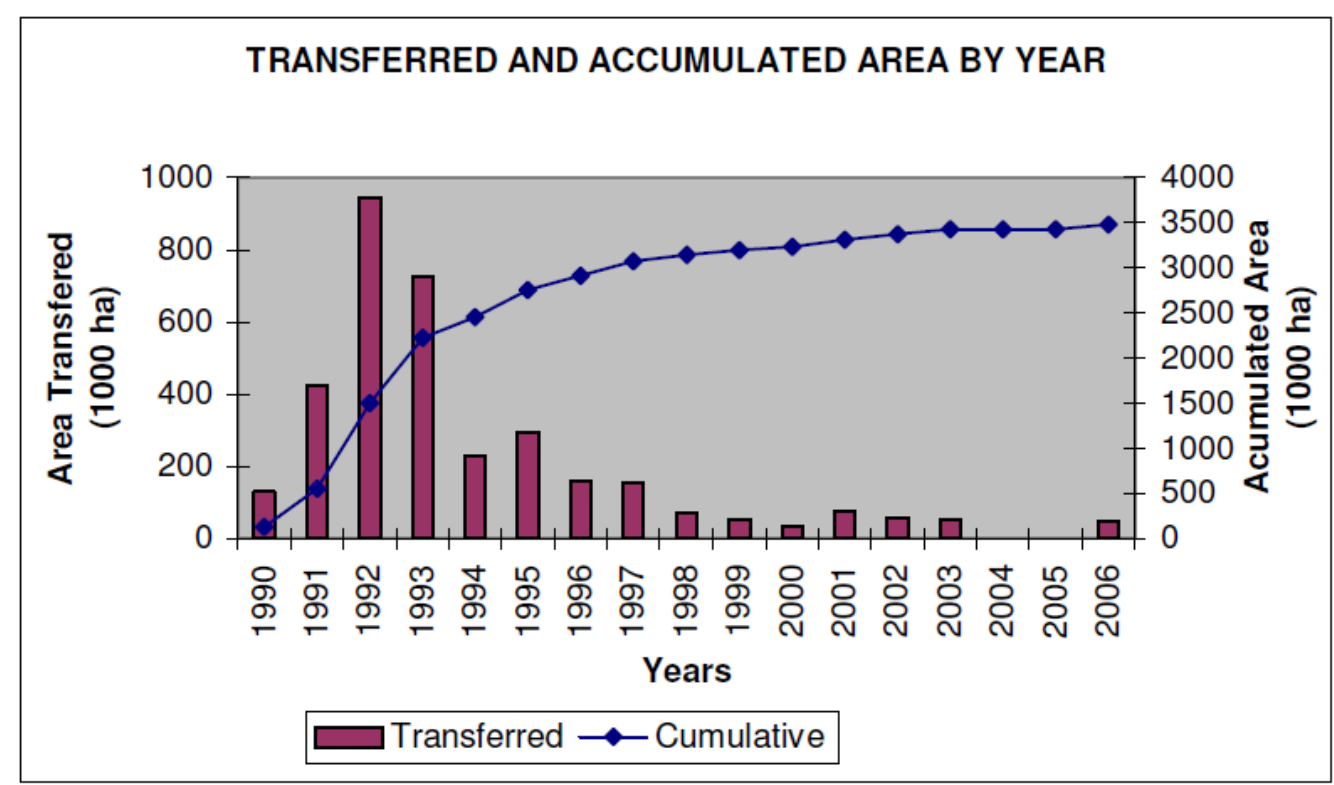

Source: Adapted from CNA, 1999 for years 1990-2000; Adopted from Unified System of Water Basic Information, (SUIBA,CNA) for years 2000-2002; ANUR (2003; 2006)

*(Taken from Silva and Garcés-Restrepo, 2002);

By 1996, 372 water user associations had been formed to control water delivery to 2.92 million hectares (Arredondo Salas and Wilson 2004). During this time water prices increased by $45-180 \%$ and government O\&M subsidies had been removed. Molle and Berkoff (2007), citing other sources, claim that O\&M charges have been quite low (equivalent to $2-7 \%$ of the gross product), and that maintenance may be suboptimal in many cases.

According to the Mexican law, in transferred districts, farmers must pay an irrigation service fee to the district, and another one to the National Water Commission (Comisión Nacional del Agua, CNA). In both cases, the paid charge must suffice to all administration and O\&M costs (Trava Manzanilla, 2002). In principle, farmers' contributions would be distributed as follows: $25 \%$ for operation; $50 \%$ for O\&M; $15 \%$ for administration; and $10 \%$ for the Department of Irrigation Engineering and Drainage (a Federal agency). Upon transferring the districts, the associations refused to pay the latter and proceeds were assigned to the operations account. After de devaluation of the peso in the mid-1990s, tariffs were realigned with the costs and were raised in 1997. Trava Manzanilla (2002) reported full supply cost recovery rates of $60 \%$ on average, and $80 \%$ in the most technically advanced districts. The size of districts in Mexico has grown from an average of 7,000 ha by the time they were transferred to the WAU to 15,000 ha after several functioning years. Scale economies are sought from merging districts.

Arredondo Salas and Wilson (2004) consider that the social benefits of the IMT appear to be far greater than the reported social costs. New WUA exhibit better performance, have enabled more farmers participation. What is also remarkable is that water deliveries' reliability has also increased, with significant positive impacts in water and land productivity which come from better exports potential. These authors conclude that higher charges were translated in better and more timely water services, which at the were more than compensated by more valuable and greater harvests.

Wilder and Romero Lankao (2006) looked in detail at two Irrigation districts in the State of Sonora (the most important in terms of irrigated acreage): Rio Yaque and Caborca. In the first, water fees increased by $257 \%$ from 1992 to 2000 . Although water allowed per hectare decreased by over $30 \%$, the cost of water (CNA and irrigation district fees) increased by nearly $100 \%$ (Wilder and 
Romero Laskao, 2006). In the Caborca district, during 1994-2000, water costs increased by $87 \%$ for industrial grapes, $89 \%$ for wheat, $118 \%$ for table grapes, and $186 \%$ for asparagus. Standing alone, water prices themselves are manageable for Yaqui and Caborca producers, largely because water fees were so low (in absolute terms) at the beginning of the reform program. However, it is the full supply cost pricing of water combined with dramatic increases in costs of electricity, seeds, fertilizer, and other formerly subsidized agricultural inputs that has created insurmountable financial problems for many producers because market prices for crops have tended to be either stagnant or falling (Wilder and Romero Laskao, 2006).

Full supply cost recovery rates have been evaluated at 1 cent of euro per $\mathrm{m}^{3}$, which represent on average 4 to $8 \%$ of the crop production costs (Trava Manzanilla, 2002). Moving to a two-part tariffs has been considered for years, but districts fear that water supply stability will translate in revenue instability and financial stress.

Arredondo Salas and Wilson (2004) analyse two transferred districts that have achieved 100\% cost recovery rates. As to year 2000, two modules of district 10 District in the Culiacán Region (State of Sinaloa) had already been transferred to the WUAs with signs of productivity growth and institutional performance.

Table 13. Examples of irrigation tariffs in Mexico

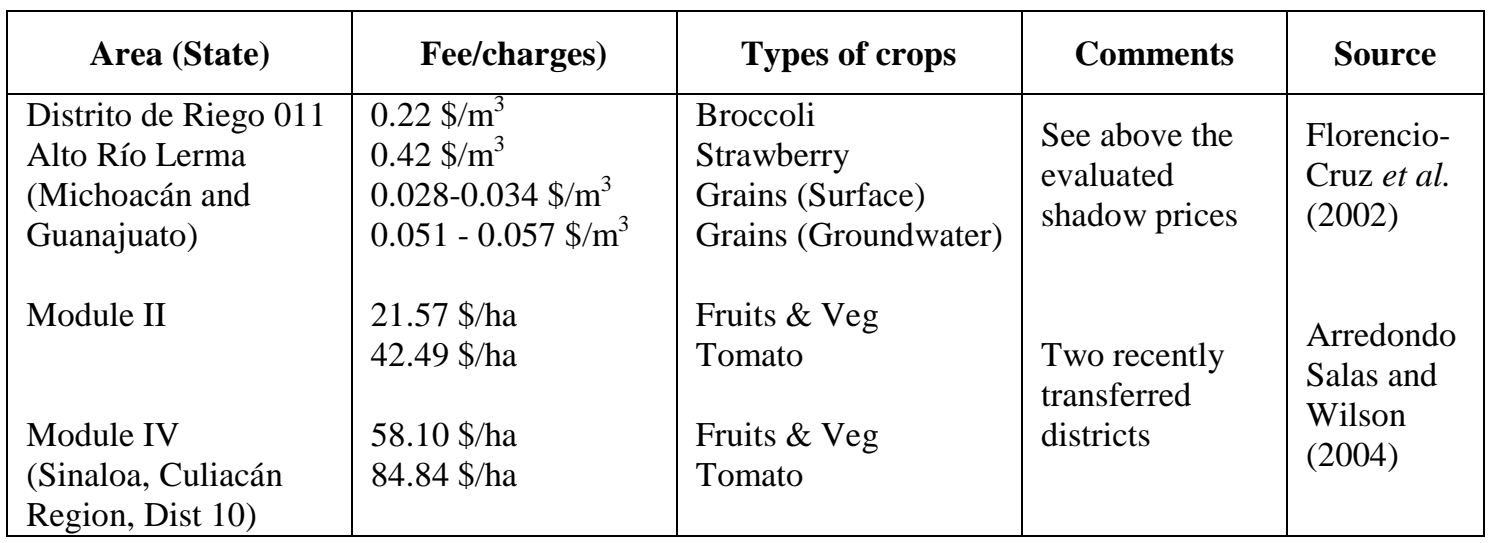

Figure 3 plots the full supply cost recovery rates for Mexico's irrigated agriculture. Mexico is one of the most advanced OECD countries in the performance of collective irrigation institutions.

Figure 4 plots the O\&M costs of various districts against size in the horizontal axis (in 1,000 ha), as evaluated by Santos-Hernández et al. (2000). These authors find that O\&M and administration costs should be in the range of 100 to $374 \$$ /ha, based on an evaluation of 11 irrigation modules of the Guanajato State.

\section{Policy conclusions}

In the last ten years, significant progress has been made in OECD countries in the area of agricultural water pricing. In practical terms, countries have made important efforts to review their irrigation pricing systems, evaluate their effects and measure cost-recovery rates. Cost evaluation procedures have been reviewed and new data has been collected at irrigation modules, districts, basin and national levels. 
Figure 3. Full supply cost recovery rates in irrigated acreage in Mexico*

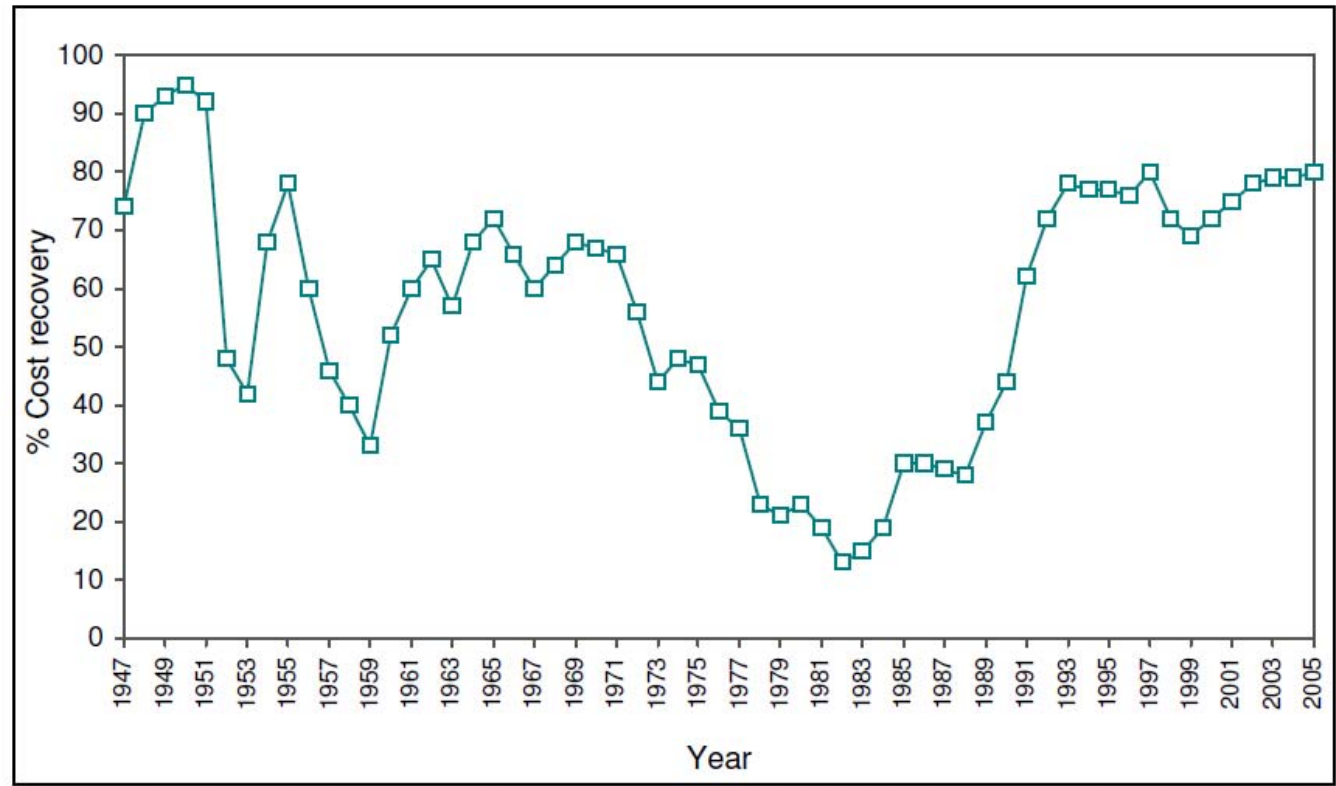

Sources: Period 1947-1990: Johnson, 1997: figure 3, page 8; period 1989-2000: ANUR (2001); period 2002-2005: ANUR (2006). Data for other years was extrapolated.

*(From Silva Ochoa and Garcés-Restrepo, 2002)

Figure 4. Average operation and maintenance costs versus irrigated acreage in eleven irrigation modules in Guanajuato

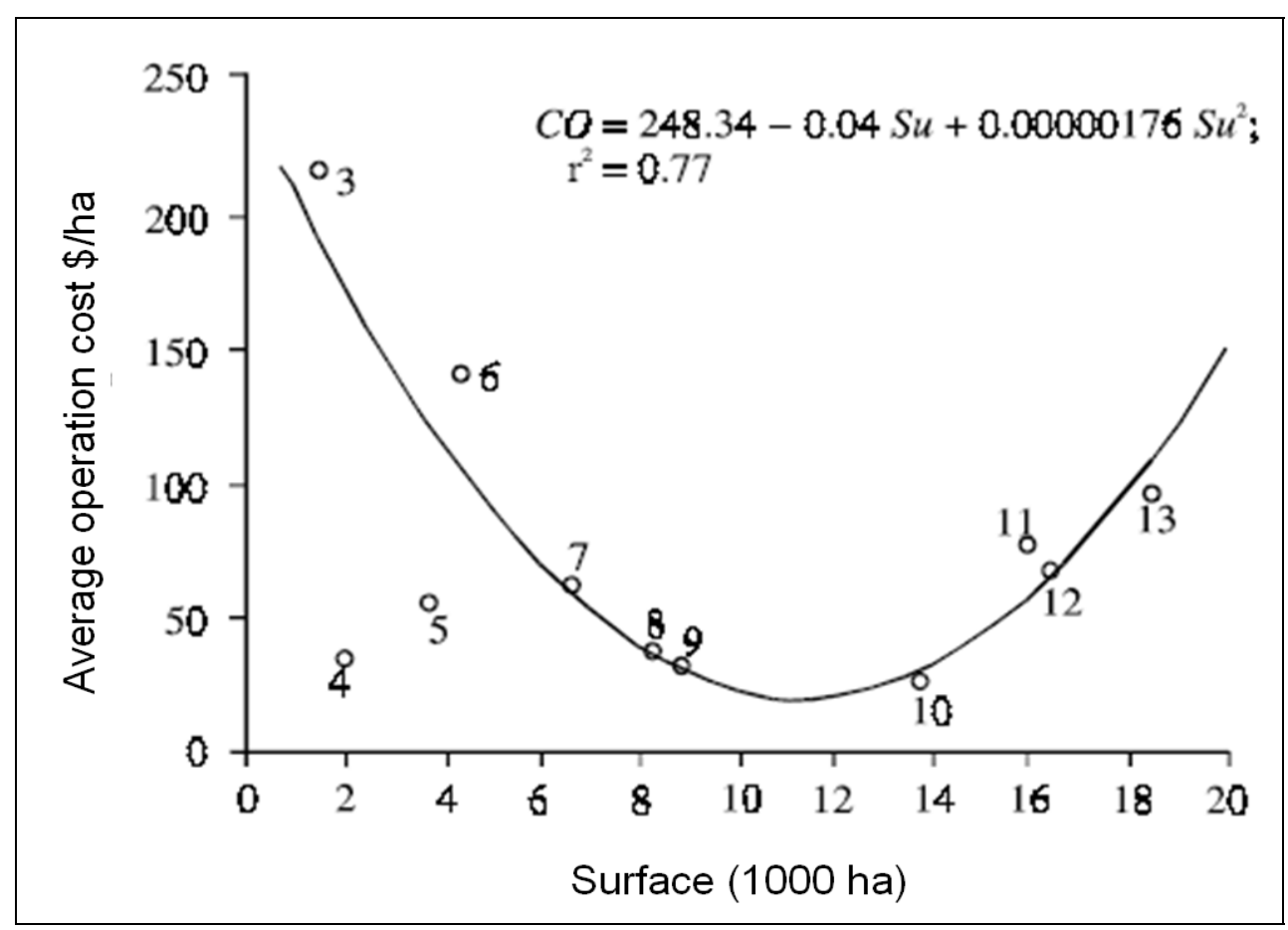

*(Taken from Santos-Hernández et al., 2000) 
In parallel, unprecedented academic efforts in all countries where irrigation is a major water user have produced numerous analyses with serious policy implications. Molle and Berkoff (2007) and Tsur et al (2004) perhaps best summarise the findings of this wealth of empirical work, and suggest a reasonable degree of agreement among researchers. The major conclusions are:

- Politicians and practitioners should lower the expectations from irrigation pricing policies. This conclusion is applicable to water demand effects, cost-recovery rates, environmental effects and even institutional effects. Yet, in situations where water scarcity is suffered, supply systems must be flexible and greased enough to ensure that service's quality does not deteriorate. The best performing test of full-cost recovery rates is found in times of scarcity and when finely-tuned water deliveries must be carried out.

- Most analyses suggest that irrigation water demand is inelastic. This does not mean that water demand is necessarily stable. Quite the contrary, most analyses show that water demand is very responsive to: (a) agricultural and environmental policies; (b) farm prices; (c) technological breakthroughs. Since water is very rarely charged at its true opportunity cost, it is misleading to attribute water use differences across districts, regions or basins to the tariffs differences.

- The environmental effects of water pricing policies are subject to similar considerations.

- Water supply costs are difficult to evaluate and subject to numerous crucial and dubious assumptions. In particular, the evaluation of capital costs of water supply must overcome serious complexities, most of them related to (a) the fact that many multipurpose infrastructures are shared with other users; (b) projects are implemented in piece-meal components along decades of planning and execution; (c) replacement costs are difficult to evaluate.

- O\&M costs are also subject to considerable scope for discussion. Even if on paper O\&M costs are fully recovered, that does not mean that appropriate provisions for required maintenance and management are made.

- As a result of such inconsistencies and poor cost definitions, it is difficult to compare full supply cost recovery rates across studies.

- Net income effects of pricing policies are in the most recent analyses (since 2004) less harmful than the predictions found in the studies published in the late 1990s. This is because water productivity has grown and, especially in the EU, less distorted agricultural policies have given farmers more flexibility to adapt their water demands.

- There is a trade-off between keeping farmers' profits, meeting the environmental targets and reducing water demand. In general, non-point farms' pollution is not efficiently tackled by water charges.

This rather sceptical evaluation of the published studies on the subject does not mean that in practical terms EU countries and Mexico have not made progress. For one thing, serious studies have been carried out to gather and compile quite dispersed economic and financial information with the sole purpose to estimate cost-recovery rates and costs involved in servicing irrigated farms. ${ }^{4}$ This report shows that a preliminary analysis on water charges and cost-recovery rates is possible for most countries. From this, it can be concluded that O\&M costs are reasonably covered, capital costs poorly covered and resource and environmental costs totally neglected by pricing policies, though there may be addressed by other policy instruments. It is no coincidence that EU Members States provide capital subsidies to their irrigators in the form of preferential schemes towards capital costs recovery. Subsiding inputs like irrigation water is one direct and simple way to help them be more competitive. This form of subsidies is concealed in a myriad of EU, national, regional, local or basin programmes, whose evaluation the member states themselves struggle to come to terms with. Preparing the WFD

4. In fact, some countries, such as France have set up mechanisms for the periodic collection of data on water prices and costs (MEDD, 2005). Spain has also a comprehensive data gathering system for the management of water resources (www.marm.es ) 
Art.5 reports has been a daunting task for all EU member states, a difficulty reflected in the European Commission reports on WFD implementation (EC, 2007).

Most OECD countries share similar definitions of water rights and grant broad scope to government agencies to allocate and ration scarce water resources. This role is nowhere assigned to pricing policies or water markets, although Spain and Mexico have introduced some market flexibility to facilitate water exchanges.

This report has provided full supply cost recovery rates for France, Portugal, Spain, Greece and Mexico, obtained from official sources, and for Italy only from academic sources. The rates are comparable across the six countries and bear similar interpretations:

- Farmers' contributions barely suffice to run the collective irrigation schemes, and perhaps part of the basin's management costs.

- Water must be metered before it can be charged volumetrically. While allocations can be made at wholesale and basin levels, the individual farmers' consumptions cannot be controlled in most irrigated areas serviced from surface waters. The economic incentive to conserve water is thus absent at the farm level.

- Tariffs are never set to allocate scarce water resources. Quotas, allocations or annual entitlements are the usual allocative mechanisms. The resource cost component is implicit in quotas, use rights and other rationing mechanisms. The option to use these instruments instead of water pricing does not mean that the farming sector is sheltered from water scarcity periods.

- In case of major projects of rehabilitation, modernization or refurbishment of infrastructures, government agencies will not only bear a great part of the costs, but also lead the project formulation, plan the action and commission the actual works. Farmers and their WUAs will participate in these plans, but taxpayers generally pay the largest share of the cost.

- Keeping irrigation districts in good operative status ensures not only that farms will be more efficiently irrigated, but also that water use, pollutants and environmental effects will likely be better monitored. This is a prerequisite for the full integration of farmers' water use into sophisticated decision support systems that control for water quantity and quality. The older the irrigated acreage in a basin or region is, the most pressing the need of subsidising the types of modernisation programmes that traditional irrigation schemes will require.

- No country provides transparent information at district or irrigation scheme levels on actual subsidies rates. All available information is offered at basin or demarcation levels, except for numberless academic sources on which many case studies and more detailed analysis offer valuable information about water tariffs and cost-recovery rates. 


\section{Bibliography}

Aiello, G.M., G. Cané, G. Fadda, A. Murrau and V. Onanao (1997). "Caratteristiche dell' irrigazione colletiva in Sardegna”. Revita Irrigazione e Drenaggio 44: 58-63.

ANBI (1992) L'uso irriguo delle acque. Associazione Nazionale Bonifiche Irrigazioni. Roma.

ANBI (1998) La verità su un territorio bonificato: l'Italia. Associazione Nazionale Bonifiche e Irrigazioni. Roma.

APAT (2006). Annuario dei dati ambientali, Edizione 2005-2006. Agenzia per la Protezione dell'Ambiente e per i Servizi Tecnici (APAT), Ministero dell'Ambiente e della Tutela del Territorio e del Mare (MATTAM), Roma.

Arredondo Salas, S., and P. Wilson "A Farmer-Centered Analysis of Irrigation Management Transfer in Mexico." Irrigation and Drainage Systems 18 (2004):89-107.

Arriaza, M., Gómez Limón J.A., and Ruiz, P. (2003) Evaluación de alternativas de desacoplamiento total de ayudas COP: El caso de la agricultura de regadío del Valle del Guadalquivir. Economía Agraria y Recursos Naturales 6,129-153.

Arrojo, P. 2001. Valoración de las aguas subterráneas en el marco económico general de la gestión de aguas en España [Groundwater valuation in the general economic framework of water management in Spain. In La economía del agua subterránea y su gestión colectiva [The economics of groundwater and collective management], edited by N. Hernández and M.R. Llamas. Madrid, Spain: Fundación Marcelino Botín and Editorial Mundi-Prensa 3-39.

Barbero, A. (2005) The Spanish National Irrigation Plan. OEDC Workshop on Agriculture and Water: Sustainability, Markets and Policies, 14-18 November, 2005. Adelaide, South Australia. Oral presentation.

Bartolini, F., G.M. Bazzani, V. Gallerani, M. Raggi, and D. Viaggi (2007). The impact of water and agriculture policy scenarios on irrigated farming systems in Italy: An analysis based on farm level multi-attribute linear programming models. Agricultural Systems, 93: 90-114.

Bazzani G.M., D’Amore A., Di Pasquale S., Fabbri A., Gallerani V., Gomez Barbero, M. and Viaggi, D. (2003) La agricoltura de regadìo en Italia y el impacto de la directiva marco de aguas. In: FENACORE (ed.) La agricultura de regadio europea y la directiva marco de aguas. Federación Nacional de Comunidades de Regantes, Madrid, pp. 139-172

Bazzani, G., S. di Pasquale, V. Gallerani, and D. Viaggi (2005) "Water framework directive: exploring policy design issues for irrigated systems in Italy." Water Policy 7:413-28.

Bazzani, G.M.; Pasquale, S.D.; Gallerani, V.; Morganti, S.; Raggi, M.; Viaggi, D. (2005) "The sustainability of irrigated agricultural systems under the Water Framework Directive: first results" Environmental Modelling \& Software 20, 2, 165-175.

Berbel, J. (2005) Análisis económico del agua en la Directiva Marco. Su aplicación a la Cuenca del Guadalquivir. Conferencia ISR, Córdoba, Spain, 28/abril/2005. Available at: www.isrcer.org/jornadas.asp

Berbel, J. and Gutierrez, C. (eds.) (2005) Sustainability of European Irrigated Agriculture under Water Framework Directive and Agenda 2000. EUR 21220. Office for Official Publications of the European Communities. Luxembourg:

Berbel, J., Calatrava, J. and Garrido, A. (2007) "Water pricing and irrigation: a review of the European experience" In F. Molle,. J. Berkoff (eds). Irrigation Water pricing Policy: The Gap Between Theory and Practice. CABI, IWMI, 295-327. 
Bontemps, C., Couture, S. and Favard P. (2003) 'Estimation de la demande en eau d'irrigation sous incertitude. (Irrigation Water Demand Estimation. With English summary).' Economie Rurale July-Aug:17-24.

Bragança, J. (1998) Portugal, personal communication.

Calatrava, J. (2002). "Los mercados de agua en la agricultura y el riesgo económico: una aplicación en el valle del Guadalquivir". Tesis doctoral, Universidad Politécnica de Madrid, Madrid.

Calatrava, J. and A. Garrido (2001a). "Análisis del efecto de los mercados de agua sobre el beneficio de las explotaciones, la contaminación por nitratos y el empleo eventual agrario". Economía Agraria y Recursos Naturales 1(2):149-170. 2002.

Calatrava, J. and Garrido, A. (2001b). "Agricultural Subsidies, water pricing and farmers' response: Implications for water policy and CAP reform". In Dosi, C. (ed) "Agricultural Use of Groundwater: Towards Integration between Agricultural Policy and Water Resources Management”, Kluwer Academic Publishers, Dordrecht. Pp 241-257.

Calatrava, J. and S. Sayadi. 2005. Economic valuation of water and willingness to pay analysis in tropical fruit production in Southeastern Spain. Spanish Journal of Agricultural Research 3(1): 25-33.

Carles, J., García, M. and Avellá, L. (2001) Aspectos económicos y sociales de la utilización de las aguas subterráneas en la Comunidad Valenciana. In: Hernández, N. and Llamas, M.R. (ed.) La economía del agua subterránea y su gestión colectiva. Fundación Marcelino Botín and Editorial Mundi-Prensa. Madrid. Pp. 153-173.

Castellano, E., P. de Anguita, J. Elorrieta, M. Pellitero, and C. Rey "Estimating a socially optimal water price for irrigation versus an environmentally optimal water price through the use of Geographical Information Systems and Social Accounting Matrices." Environmental and Resource Economics 39 (2008):331-56.

Castro, J. (1997). "Portugal". In Water Pricing Experiences. An International Perspective. (Ed. A. Dinar and A. Subramanian). World Bank Technical Paper 386. Washington, DC. 99-103.

CGGREF (2005). "Irrigation durable”. Rapport CGGREF N² 2185.Conseil Général du Génie Rural, des Eaux et des Forêts (CGGREF), Ministère de l'Agriculture, de l'Alimentation, de la Pêche et de la Ruralité, Paris.

Chakravorty, U. and Roumasset, J. (1991) Efficient spatial allocation of irrigation water. Amer. J. Agr. Econom. 73, 165-73.

Chartzoulakis, K.S. and Angelakis, A.N. (2001) Water resources management in Crete (Greece) with emphasis in agricultural use. Transnational Workshop on Managing Water in agriculture through Pricing: Research Issues and Lessons Learned. CNR-ISPAIM, Ercolano, Italy, 24-26 May.

Chohin-Kuper, A., Rieu, T. \& Montginoul, M. (2002). Les outils économiques pour la gestion de la demande en eau en Méditerranée. Séries Irrigation "Rapports" 2002-06 ; 1081 Cemagref.

Chohin-Kuper, A.; Rieu, T. and Montginoul, M. (2003). Water policy reforms: Pricing water, cost recovery, water demand and impact on agriculture. Lessons from the Mediterranean experience. Water pricing Seminar, Barcelona, June 30-July 2.

CHS (2007). Estudio General sobre la Demarcación Hidrográfica del Segura (versión del 2 de julio de 2007). Confederación Hidrográfica del Segura, Murcia, Spain.

Comité du Bassin Adour Garonne (2005). L'état des ressources en eau du Bassin Adour-Garonne. Consultation du public mai-octobre 2005. Agence de l'eau Adour Garonne, Toulouse.

Comité du Bassin de la Guadeloupe (2005). Etat des lieux Directive Cadre. District Guadeloupe. Direction Régionale de l'Environnement, Basse-Terre, Guadaloupe. 
Comité du Bassin Rhône-Méditerranée (2005). Etat des lieux du bassin du Rhône et des cours d'eau côtiers méditerranéens. Caractérisation du district et registre des zones protégées. Agence de l'Eau Rhône Méditerranée \& Corse, Lyon.

Corominas, J. 2001. El papel económico de las aguas subterráneas en Andalucía [The economic role of groundwater in Andalusia]. In La economía del agua subterránea y su gestión colectiva [The economics of groundwater and collective management], edited by N. Hernández and M.R. Llamas. Madrid, Spain: Fundación Marcelino Botín and Editorial Mundi-Prensa, 111-139.

Dechmi, F., E. Playán, J.M. Faci and M. Tejero. 2003. Analysis of an irrigation district in northeastern Spain: I. Characterisation and water use assessment. Agricultural Water Management 61: 75-92.

Dinar, A. y Letey, J. (1991). Agricultural water marketing, allocative efficiency and drainage reduction. Journal of Environmental Economics and Management 20: 210-223.

Dono, G. and Severini, S. (2001) The Agenda 2000 CAP Reform and Its Impact on Irrigation Water Use: A Regional Programming Model for a Central Horticultural Area. Transnational Workshop on Managing Water in Agriculture through Pricing: Research Issues and Lessons Learned. CNR-ISPAIM, Ercolano, Italy, 24-26 May.

Dubois De La Sablonière, F. (1997) France: An Incentive Policy for Sustainable Management of Irrigation Water in the Loire-Brittany Basin. OEDC Workshop on the Sustainable Management of Water in Agriculture: Issues and Policies. Directorate for Food, Agriculture and Fisheries and Environment Directorate, Athens, Nov. 3-6.

Duchein A. (1997) France: Partnership between the Agricultural Community and the Basin Agencies. OEDC Workshop on the Sustainable Management of Water in Agriculture: Issues and Policies. Directorate for Food, Agriculture and Fisheries and Environment Directorate, Athens, Nov. 3-6.

EC (2000). Pricing Policies for Enhancing the Sustainability of Water Resources. Communication from the Commission to the Council, the European Parliament, and the Economic and Social Committee. COM (2000) 477 final. European Commission, Brussels.

EC (2003). WATECO. Economics and the Environment. The Implementation Challenge of the Water Framework Directive. Accompanying Documents to the Guidance. European Commission, Brussels.

EC (2007). Communication from the Commission to the European Parliament and Council: Towards sustainable water management in the European Union - First stage in the implementation of the Water Framework Directive 2000/60/EC. COM(2007) 128 final. European Commission, Brussels.

Farrace, M.G. (2007). "Italy”. In Mediterranean Action Plan (MAP), Water demand management, progress and policies: Proceedings of the 3rd Regional Workshop on Water and Sustainable Development in the Mediterranean, Zaragoza, Spain, 19 - 21 March 2007. MAP Technical Reports Series No. 168. United Nations Environment Programme / Mediterranean Action Plan (UNEP/MAP), Athens, Greece, 309-346.

Florencio-Cruz, V. Valdivia-Alcalá, R. and C.A. Scout. "Productividad del agua en el distrito de Riego 011, Alto Río Lerma. Agrociencia 36: 483-493. 200.

Gallerani, V. and Viaggi, D. (2003). Water management and the sustainability of irrigated farming systems in a contract perspective: experiences in northern Italy. Economics of Contracts in Agriculture, Third annual workshop, June 19-21, Copenhagen, Denmark.

García Mollá, M.(2002). Análisis de la influencia de los costes en el consumo de agua en la agricultura valenciana. Caracterización de las entidades asociativas para riego. Tesis doctoral. Departamento de Economía y Ciencias Sociales. Universidad Politécnica de Valencia, Valencia. 
García, M., Carles, J. and Sanchís, C. (2004). Características institucionales y territoriales y su influencia en el costo del agua como input en la agricultura. VII Congreso Nacional de Medio Ambiente. Madrid (Spain), 22-26 november.

Garrido, A. and Varela-Ortega, C. (2008). Economía del agua en la agricultura e integración de políticas sectoriales. Panel Científico técnico de seguimiento de la política de aguas. University of Seville and Ministry of the Environment. Seville, January 2008.

Gómez-Limón, J. A., Arriaza, M. and J. Berbel, J. (2002) Conflicting implementation of agricultural and water policies in irrigated areas in the EU. Journal of Agricultural Economics 53, 2, 259.281.

Gómez-Limón, J.A., and L. Riesgo (2004). "Irrigation water pricing: differential impacts on irrigated farms." Agricultural Economics, 31:47-66.

Hafi, A., Klijn, N. and Kemp, A. (2001) Efficient Pricing and Allocation of Irrigation Water. A Model of the Murrumbidgee Irrigation Area. ABARE Conference Paper 2001.4, Canberra. available at www.pc.gov.au/research/swp/rdia/

Hernández, N. and Llamas, M.R. (ed.) (2001) 'La economía del agua subterránea y su gestión colectiva. Fundación Marcelino Botín y Ediciones Mundi-Prensa, Madrid, Spain.

Iglesias. E., Sumpsi, J. M. and Blanco, M. (2004) Environmental and Socioeconomic Effects on Water Pricing Policies: Key Issue in the Implementation of the Water Framework Directive. $13^{\text {th }}$ Annual Conference of the European Association of Environmental and Resource Economists,. Budapest, June 25-28. Unpublished.

INEA (2008). Agricoltura irrigua e scenari di cambiamento climatico. Stagione irrigua 2007 nel Centro Nord. Istituto Nazionale di Economia Agraria (INEA), Roma.

Lekakis, J. (1998). Personal communication. Greece.

Leone, G. (1997). Stato delle irrigazioni in Italia. Rivista L’Acqua, no. 5.

Malik, R.P.S. (2008). Towards a common methodology for measuring irrigation subsidies. Discussion paper for the Global Subsidies Initiative (GSI) of the International Institute for Sustainable Development (IISD), Geneva, Switzerland.

MAOTDR (2005). Relatório Síntese sobre a Caracterização das Regiões Hidrográficas prevista na Directiva-Quadro da Água. Instituto da Água, Ministerio do Ambiente, do Ordenamiento do Territorio e do Desenvolvimento Regional. Portuguese Republic, Lisbon

MAPA (2001) Plan Nacional de Regadíos. Horizonte 2008. Ministerio de Agricultura, Pesca y Alimentación, Madrid.

Margat, J. (2002). Tendances contemporaines et perspectives d'évolution des demandes en eau dans les pays méditerranéens. Plan Bleu. Sophia Antipolis.

Martínez, Y. and J. Albiac. 2004. Agricultural pollution control under the Spanis and European environmental policies. Water Resources Research 40, W10501, doi:10.1029/2004WR003102, 2004.

Martínez, Y., and J. Albiac (2006). "Nitrate pollution control under soil heterogeneity." Land Use Policy, 23 (2006):521-32.

Massarutto A. (ed.) (2001) Water Pricing, the Common Agricultural Policy and Irrigation Water Use. Draft Report for European Commission. Udine, Italy.

Massarutto, A. (2003) Water pricing and irrigation water demand: efficiency vs. sustainability. European Environment 13/2003, 100-119.

MEDD (2005). Acte de la Réunion de la formation environnement du CNIS du 9 juin 2005. Direction de l'eau, Ministère de l'Ecologie et du Développement Durable. Paris. 
Mejias, P., Varela-Ortega, C. and Flichman, G. (2004) Integrating agricultural policies and water policies under water supply and climate uncertainty. Water Resources Research 40, W07S03, doi:10.1029/2004WR002877, 2004

MEPPPW (2008). Greece: Final Report for article 5 of the Water Framework Directive. Central Water Agency, Ministry of Environment, Physical Planning and Public Works, Hellenic Republic, Athens.

MMA (2004). Júcar Pilot River Basin, Provisional Article 5 Report. Valencia.

MMA (2007) El Agua en la Economía Española: Situación y Perspectivas. Informe Integrado del Análisis Económico de los Usos del Agua. Artículo 5 y Anejos II y III de la Directiva Marco del Agua. Ministerio Medio Ambiente. Madrid.

MMA (2007) Precios y costes de los servicios de agua en España. Informe integrado de recuperación de costes de los servicios de agua en España. Artículo 5 y Anejo III de la Directiva Marco de Agua. Ministerio de Medio Ambiente. 220.

Molle, F. and J., Berkoff (eds). Irrigation Water pricing Policy: The Gap Between Theory and Practice. CABI, IWMI, 2007.

Montginoul, M. (1997) France. In: Dinar, A. and Subramanian, A. (ed.) Water Pricing Experiences. An International Perspective. World Bank Technical Paper 386. World Bank, Washington, D.C. 46-53.

Montiginoul, M. and Rieu, T. (2001) Irrigation water pricing reforms and implementing procedures: Experience acquired in Charente and in Morocco. In: Pricing Water. Economics, Environment and Society. Conference Proceedings Sintra, 6 and 7 September 1999, European Commission.

OECD (1999a) Agricultural Water Pricing in OEDC Countries. Document ENV/EPOC/GEEI(98)10/Final. OEDC, Paris.

OECD (2001) Transition to Full-Cost Pricing of Irrigation Water for Agriculture in OECD Countries. Document COM/ENV/EPOC/AGR/CA(2001)62/Final. OECD, Paris.

Peréz, L. and J. Barreiro (2007). "Una nota sobre la recuperación de costes de los servicios del agua en la cuenca del Gállego”. Economía Agraria y Recursos Naturales 7(13): 49-56.

Plan Bleu (2007). Gestion de la demande en eau en Méditerranée, progrès et politiques. Rapport de la France. ZARAGOZA, 19-21/03/2007.

Rainelli, P. and D. Vermersch (1998). Irrigation in France: Current Situation and Reasons for its Development. Unpublished manuscript from a study submitted to OECD Environment Directorate.

Riesgo, L., and J. Gómez-Limón (2006). Multi-criteria policy scenario analysis for public regulation of irrigated agriculture. Agricultural Systems 91:1-28.

Rieu, T. (2005). Water pricing for agriculture between cost recovery and water conservation: Where do we stand in France? OECD Workshop on Agriculture and Water: Sustainability, Markets and Policies 14-18 November, 2005: Adelaide, South Australia.

Santos-Hernández, A.L., E. Palacios-Vélez, D. Exebio-García y L. Chalita-Tovar. "Metodología para evaluar la distribución de costos e ingresos relacionados con el servicio de riego" Agrociencia 34: 639-649. 2000.

Semaan, J., G. Flichman, A. Scardigno, and P. Steduto (2007). Analysis of nitrate pollution control policies in the irrigated agriculture of Apulia Region (Southern Italy): A bio-economic modelling approach." Agricultural Systems, 94: 357-67. 
Silva Ochoa, Paula and Carlos Garces-Restrepo (2007) Advances of the Irrigation Management Transfer in the Large-Scale Irrigation Schemes in Mexico. Presented at the 4th Asian Regional Conference and 10th International Seminar on Participatory Irrigation Management. Teheran, Iran. May. Organized by the International Commission on Irrigation and Drainage (ICID) and the International Network on Participatory Irrigation Management (INPIM).

SRA (2006). Relatório Síntese da Caracterização das Região Hidrográfica Arquipélago da Madeira (Portugal). Direcção Regional do Ambiente, Secretaria Regional do Ambiente e dos Recursos Naturais. Madeira.

SRAM (2006). Relatório Síntese da Caracterização das Região Hidrográfica Arquipélago dos Açores (Portugal). Direcção Regional do Ordenamento do Territorio e dos Recursos Hidrícos, Secretaria Regional do Ambiente e do Mar. Açores.

Sumpsi, J.M., Garrido, A., Blanco, M., Varela, C. and Iglesias, E. (1998) Economía y Política e Gestión del Agua en la Agricultura. MAPA y (ed.).Mundi-Prensa, Madrid, 351 pp.

Trava Manzanilla, J.L. (2002), Aspectos prácticos en la transferencia de los distintos de riego a las asociaciones de usuarios. In Embid Irujo, A. (Dir). El Derecho de Aguas en Iberoamérica y España: Cambio y Modernización en el inicio del tercer milenio. Civitas, Madrid, 543-583.

Tsur, Y. and Dinar, A. (1997) The Relative Efficiency and Implementation Costs of Alternative Methods for Pricing Irrigation Water. The World Bank Economic Review 11, 2, 243-62.

Tsur, Y. et al. (2004). Pricing Irrigation Water. Principles and Cases from Developing Countries. Resources for the Future Press, Washington, D.C.

Weinberg, M., C. L. Kling,and J.E. Wilen (1993). Water markets and water quality. American Journal of Agricultural Economics 75(2): 278-291.

Wilder, M. \& P. Romero Lankao. Paradoxes of Decentralization: Water Reform and Social Implications in Mexico. World Development 34(11) November 2006, Pages 1977-1995.

Xiloyannis, C. and B. Dichio, (2001) How to Improve Water Efficiency in Fruit Trees Species in Southern Italy. Transnational Workshop on Managing Water in Agriculture through Pricing: Research Issues and Lessons Learned. CNR-ISPAIM, Er 